\title{
The Medieval Climate Anomaly and Byzantium: A review of the evidence on climatic fluctuations, economic performance and societal change
}

\author{
Elena Xoplaki ${ }^{1}$, Dominik Fleitmann ${ }^{2}$, Juerg Luterbacher ${ }^{1}$, Sebastian Wagner ${ }^{3}$, John F. \\ Haldon $^{4}$, Eduardo Zorita ${ }^{3}$, Ioannis Telelis ${ }^{5}$, Andrea Toreti ${ }^{6}$, Adam Izdebski ${ }^{7}$ \\ ${ }^{1}$ Climatology, Climate Dynamics and Climate Change, Department of Geography, Justus-Liebig- \\ University Giessen, Giessen, Germany, elena.xoplaki@geogr.uni-giessen.de \\ ${ }^{2}$ Department of Archaeology, School of Human and Environmental Sciences, University of Reading, \\ Reading, UK, d.fleitmann@reading.ac.uk \\ ${ }^{3}$ Institute for Coastal Research, Helmholtz-Zentrum Geesthacht, Geesthacht, Germany, \\ sebastian.wagner@hzg.de, eduardo.zorita@hzg.de \\ ${ }^{4}$ History Department, Princeton University, USA, jhaldon@princeton.edu \\ ${ }^{5}$ Research Center for Greek and Latin Literature, Academy of Athens, Athens, Greece, \\ itelelis@academyofathens.gr \\ ${ }^{6}$ European Commission, Joint Research Centre, Ispra, Italy, andrea.toreti@jrc.ec.europa.eu \\ ${ }^{7}$ Byzantine History Department, Institute of History, Jagiellonian University in Krakow, Krakow, \\ Poland, adam.izdebski@fundusz.org
}

Corresponding author

Elena Xoplaki, Climatology, Climate Dynamics and Climate Change, Department of Geography, JustusLiebig-University Giessen, Senckenbergstr. 1, 35390 Giessen, Germany, Email: elena.xoplaki@geogr.uni-giessen.de 


\section{Abstract}

At the beginning of the Medieval Climate Anomaly, in the ninth and tenth century, the medieval eastern Roman empire, more usually known as Byzantium, was recovering from its early medieval crisis and experiencing favourable climatic conditions for the agricultural and demographic growth. Although in the Balkans and Anatolia such favourable climate conditions were prevalent during the eleventh century, parts of the imperial territories were facing significant challenges as a result of external political/military pressure. The apogee of medieval Byzantine socio-economic development, around AD 1150, coincides with a period of adverse climatic conditions for its economy, so it becomes obvious that the winter dryness and high climate variability at this time did not hinder Byzantine society and economy from achieving that level of expansion. Soon after this peak, towards the end of the twelfth century, the populations of the Byzantine world were experiencing unusual climatic conditions with marked dryness and cooler phases. The weakened Byzantine socio-political system must have contributed to the events leading to the fall of Constantinople in AD 1204 and the sack of the city. The final collapse of the Byzantine political control over western Anatolia took place half century later, thus contemporaneous with the strong cooling effect after a tropical volcanic eruption in $A D 1257$.

We suggest that, regardless of a range of other influential factors, climate change was also an important contributing factor to the socio-economic changes that took place in Byzantium during the Medieval Climate Anomaly. Crucially, therefore, while the relatively sophisticated and complex Byzantine society was certainly influenced by climatic conditions, and while it nevertheless displayed a significant degree of resilience, external pressures as well as tensions within the Byzantine society more broadly contributed to an increasing vulnerability in respect of climate impacts.

Our interdisciplinary analysis is based on all available sources of information on the climate and society of Byzantium, that is textual (documentary), archaeological, environmental, climate and 
climate model-based evidence about the nature and extent of climate variability in the eastern

Mediterranean. The key challenge was, therefore, to assess the relative influence to be ascribed to climate variability and change on the one hand, and on the other to the anthropogenic factors in the evolution of Byzantine state and society (such as invasions, changes in international or regional market demand and patterns of production and consumption, etc.). The focus of this interdisciplinary study was to address the possible causal relationships between climatic and socio-economic change and to assess the resilience of the Byzantine socio-economic system in the context of climate change impacts.

Keywords: Medieval Climate Anomaly, Byzantine empire, climate impacts, society 


\section{Introduction}

The study of the impact of climate in the society and economy of the eastern Mediterranean and more specifically the Byzantine world during the period known as the Medieval Climate Anomaly (MCA, in this work AD 850-1300) is a challenging topic for scholars from several scientific disciplines. This review aims to contribute to the identification of relationships between climatic and socioeconomic changes. The achievement of these aims required a detailed, interdisciplinary and comparative analysis that took advantage of new evidence on medieval climate and society in Byzantium and existing textual, archaeological, environmental, climatological and climate-model based evidence. The hypotheses developed in this review offer guidance for future research on climate impacts and societal responses in the eastern Mediterranean during medieval times.

Research on the climate of the Middle Ages intensified in the 1960s with the collection of historical accounts by Lamb (1965), who documented an increase in the relative frequency of warm episodes, primarily around the northern North Atlantic and increased cold season precipitation in Britain during the medieval period. Lamb wrote first of a Medieval Warm Epoch and later of a Medieval Warm Period ending at ca. AD 1300. A large number of studies on the temporal and regional expression of the Medieval Warm Period for different parts of the world have followed since Lamb's pioneering work. A comprehensive review of these studies can be found in Hughes and Diaz (1994), Diaz et al. (2011) and Graham et al. (2011). The term Medieval Climate Anomaly (MCA) was later introduced by Stine (1994), who sought an explanation for the century-long low stands of lakes in the western North and South America. The subsequent adoption of the term Medieval Climate Anomaly reflects the increased number of studies on the climate of the medieval times since Lamb's publication. New marine and terrestrial climate proxy records with high temporal and spatial resolution, and detailed modelling studies allow for a more accurate and detailed research on the MCA in different parts of the globe (e.g., Bradley et al. 2003, Goosse et al., 2006, Esper et al. 2007; Mann et al., 2009, Graham et al., 2011, Ge et al., 2010, Guiot et al., 2010, Diaz et al., 2011, Goosse et 
al., 2012, Roberts et al. 2012; Guiot, 2012, Masson-Delmotte et al., 2013 and references therein, PAGES 2k Consortium, 2013 and references therein, and Chen et al. 2015).

Based on continental-scale surface temperature reconstructions, the Fifth Assessment Report of the Intergovernmental Panel on Climate Change (IPCC AR5) concludes with high confidence that "multidecadal periods during the Medieval Climate Anomaly (950 to 1250) were in some regions as warm as in the mid-twentieth century and in others as warm as in the late twentieth century" and that "these regional warm periods were not as synchronous across regions as the warming since the midtwentieth century" (Masson-Delmotte et al., 2013, pp. 386).

While a considerable body of terrestrial and marine palaeoclimatic information on the MCA is available for the western and central Mediterranean, temporally high resolved records are scarce in the eastern Mediterranean (Luterbacher et al., 2012 and references therein; Gogou et al., this volume). The temporal coverage and resolution of the proxy records varies significantly, and they reflect different climate signals (e.g., temperature, precipitation, drought, sea-level changes, $\mathrm{pH}$, seawater temperature, water-mass circulation and others). Palaeoclimate records show a seasonal bias due to the physiological processes involved and their chronologies are often not well constrained (Luterbacher et al., 2012). The low spatial density and heterogeneous distribution of the proxy records and their archive-specific characteristics are still a major limitation for a comprehensive characterization of the MCA in the global and regional scale and more specifically in the eastern Mediterranean (e.g., Finné et al., 2011, Luterbacher et al., 2012, Kaniewski et al. 2012, Roberts et al., 2012 and Bakker et al. 2013).

Palaeoclimate models enable studies of the driving dynamical mechanisms that could lead to thermal or hydrological periods deviating from mean climate conditions and are caused, for example, by the influence of the ocean on the adjacent continents or by changes in atmospheric circulation patterns. Analysing palaeoclimate records and models together allows for the evaluation of past climate 
transitions and the assessment of forcing and feedback mechanisms. In return, climate model simulations can contribute to the interpretation of potential causes of variations observed in the palaeoclimate data. In this context, recent modelling studies have already indicated the very heterogeneous patterns that prevailed during the MCA, related to i) different regions, ii) various investigated climate models and iii) different timings and seasonality of the main phases of the MCA (e.g., Graham et al., 2011 and Fernández-Donado et al., 2013, among others). In order to interpret the spatial heterogeneity of the MCA climatic patterns, changes in external forcings (solar and volcanic activity) as well as changes in the internal modes of climate variability (related to the atmospheric circulation, such as Arctic Oscillation, North Atlantic Oscillation, or the coupled atmosphere-ocean patterns, e.g., Atlantic Multidecadal Oscillation) need to be taken into account, especially on the sub-continental to regional scale (e.g., Goosse et al., 2006, Graham et al., 2011 and Goosse et al., 2012). Moreover, compared to the subsequent period of the Little Ice Age, the influence of strong and sustained changes in external forcings, such as great solar minima or large tropical volcanic eruptions, are found to be rather small (e.g., Goosse et al. 2012, Euro_Med Consortium, 2015). Regional climate model simulations (e.g., Gómez-Navarro et al., 2013) can be used to investigate how the suite of external forcings might influence changes in the regional climate. Such analysis is, however, complicated by various sources of uncertainty, including uncertainties in the reconstruction of the external forcings, the coarse resolution of climate models, and the parameterizations of certain processes due to simplifications used within the climate models (Gómez-Navarro et al., 2013). Ensemble simulations, driven by the same forcing parameters and the same climate model, enable the characterisation of the bandwidth of the internal climate anomalies due to different trajectories, caused by the slightly different initial conditions, in the individual ensemble members. The term "anomalies" is used here for deviations from a reference period, i.e. with respect to the twentieth century or the period AD 1500-1850. 
In recent years efforts have been made to assimilate empirical information into climate models

(Widmann et al., 2010). To date this is however only achieved for Earth System Models of Intermediate Complexity (Goosse et al., 2012) and only very few studies like Jones and Widmann (2004) try to implement this into an atmosphere only general circulation model (GCM) to nudge the Arctic Oscillation towards a specific state. A recent study by Matsikaris et al. (2015) uses an on-line and off-line data assimilation of continental PAGES2k reconstructions for the Maunder Minimum. Other approaches try to implement data assimilation for climate field reconstructions in the context of pseudo proxy experiments (Steiger et al., 2014). One advantage of assimilated simulations is that they carry some degree of information about the true climatic evolution given that the assimilated proxy time series include sufficient climate-related (i.e., temperature or precipitation) variance. Conventional free simulations like the ones used in this study allow investigations of the full spectrum of different climate states given a certain set of external forcings. Also the comparison between the GCM output and the proxy data can be carried out on an independent basis allowing a more rigorous testing of the climate models.

Culturally and geo-politically the Byzantine empire was simply the reduced eastern part of the Roman empire that continued in existence as a major political power after the disappearance of the western parts of the empire during the second half of the fifth century. After the catastrophic events that the Byzantine empire experienced in the later sixth and seventh centuries $A D$, including the loss of the Levant (by AD 638), Egypt (by AD 642) and North Africa (by the AD 690s) to the Arabs, of most of the Balkans to the Slavs and Avars (over a longer period, AD 580s to AD 640s), and of much of Italy to the Lombards (from the AD 580s into the early eighth century), it struggled to survive in the face of the Arab threat in particular (Haldon, 1997). From the early ninth century, however, a period of relative internal political, fiscal and military stability set in. The Byzantine empire while reduced to a rump of its former territories in the northern part of the eastern Mediterranean, was a stable and expanding society with a thriving economy and complex political-cultural institutions, as well as a 
societal organisation among the most sophisticated achieved by pre-modern societies (Haldon, 1993). The Byzantines produced a considerable body of written and material evidence that permits to investigate the potential societal impacts of climate variability for a period of prosperity of the Byzantine empire between the ninth and twelfth century $A D$ in close detail. The key dates for medieval Byzantine history are presented in Table I.

The empire slowly consolidated its power over Anatolia and what is now Greece, a process that accelerated in the second half of the ninth century after the accession of Basil I (AD 867-886) to the throne. Basil was the founder of the so-called Macedonian dynasty, which ruled for more than 150 years until the middle of the eleventh century, during which period the empire achieved enormous success in military terms, recovering many former eastern provinces and extending its borders to take in Antioch (northern Syria) and Armenia. The empire achieved its largest territorial extent during the years immediately following the death of Basil II (AD 976-1025, Cheynet, 2004a). It was also during the period of dominance of this dynasty that the long process by which the social élite of the empire transformed into an aristocracy was completed. Of a predominantly military character, its power rivalled that of the central government and court, although it was seldom united in opposition (Cheynet, 2000; Haldon 2009a). A period of internal political conflict set in during the AD 1030s, exacerbated by fiscal problems, factional conflict within the élite, and new military pressures on several fronts from the Normans in the west, Pecheneg nomads in the Balkans, and the Seljuk Turks in eastern Anatolia. The defeat at Mantzikert in AD 1071 proved to be a turning point, less because it led directly to Turkish conquest, but rather because it immediately sparked a civil war that effectively destroyed the eastern Roman military and political cohesion and resistance. Alexios I Komnenos (AD 1081-1118) was able to stabilize and begin to reverse the situation, notably through effective military and diplomatic action as well as through a series of fiscal and administrative reforms. The rule of his successors from the dynasty of the Komnenoi was initially successful, ensuring a period of peace and stability, at least in Greece and the wider Aegean region. While the empire reached a political nadir 
by the AD 1080s, a remarkable recovery followed, culminating in the middle of the twelfth century under the emperor Manuel I (AD 1143-1180), before a final collapse led to the sack of Constantinople in AD 1204 and the establishment of a Latin empire (see Table I for further details). Even though the Byzantines managed to reconquer their capital in $A D 1261$, they did not succeed in reviving the empire in its pre- AD 1204 shape. Most of the evidence on economic performance and societal change in Byzantium comes from the Aegean and the neighbouring regions of Bulgaria and western Anatolia (Koder, 1984; Laiou et al. 2002; Laiou and Morrisson 2007 and Sections 2 and 3 below) that also form the geographical focus of this review (Fig. 1). The chronological scope of this work, ca. AD $850-1300$, begins with the recovery of the Byzantine state and economy after the early medieval crisis noted above (Haldon 1997; Haldon et al. 2014; general surveys of the relevant periods in Jeffreys, Haldon et al. 2008) and ends with the period that followed the fall of Constantinople, the imperial capital, in AD 1204 to the Latin armies of the Fourth Crusade. In this work, MCA coincides very broadly with the middle Byzantine period (ca. AD 800-ca. 1200, as currently defined in the archaeological literature) and the beginning of the climate models simulations.

Table I. Key dates in the history of Byzantium, AD 800-1300

\begin{tabular}{|c|c|}
\hline Year AD & Key events and reigns \\
\hline 838 & $\begin{array}{l}\text { Sack of Amorion (central Anatolia), the last of the serious Byzantine defeats at the } \\
\text { hands of the Arabs }\end{array}$ \\
\hline 867-886 & Basil I, founder of the Macedonian dynasty and the initiator of a major legal reform \\
\hline $962-965$ & Cilicia conquered by Nicephorus II \\
\hline 972-975 & $\begin{array}{l}\text { Byzantines invaded Syria and Palestine under the command of the emperor John I } \\
\text { Tzimiskes }\end{array}$ \\
\hline 976-1025 & Basil II, conquest of Armenia and Bulgaria, the height of the Byzantine political power \\
\hline 1071 & $\begin{array}{l}\text { The Seljuk Turks defeat the Byzantines at Mantzikert, civil war leading to loss of much } \\
\text { of Anatolia }\end{array}$ \\
\hline 1081-1118 & Alexios I Komnenos; reconquest of most of Western Anatolia; political stability regained \\
\hline 1204 & $\begin{array}{l}\text { The Fourth Crusade and the fall of Constantinople to the Latins; political disintegration } \\
\text { of the empire }\end{array}$ \\
\hline 1261 & Byzantines from Nicaea recaptured Constantinople under Michael VIII Palaiologos \\
\hline
\end{tabular}

The paper is structured as follows: Section 2 introduces potential climate impacts on Byzantine society and economy and is followed by Section 3 and the elaboration of the quantitative data on the 
economic performance of the middle Byzantine period. In Section 4, recent climatic conditions of the study area are briefly presented, with the aim of providing information on the spatial climate variability of the northern part of the eastern Mediterranean together with palaeoclimate records and model simulations, so that the medieval climate at the regional scale can be assessed in comparison with historical and archaeological information. Finally, hypotheses about potential impacts of climate variability during the medieval times on Byzantine society are discussed in an interdisciplinary analysis.

\section{Potential impact of climate and its variability on the Byzantine state and economy during medieval times}

Byzantium was primarily dependent on agriculture (Harvey, 1989; Kaplan 1992; Lefort 2002) and therefore vulnerable to fluctuations in climatic conditions. Consequently, the analysis carried out in the next sections focuses on agricultural production during the middle Byzantine period. Table II presents the most important Byzantine crops. These crops either formed a substantial portion of the diet (cereals) of the Byzantines or functioned as primary traded goods (e.g., vine, olive). Byzantine and modern agronomic literature provide information on key seasons and weather conditions for agricultural production. The most relevant key seasons for the cultivation, harvest volume, and quality of the crops are considered in the proxy- and model-based analysis for the medieval period in Section 4.

Table II. Important crops for the Byzantines. Key seasons and threatening weather conditions and their role in society. Information derived from: Psellus, Peri georgikon, ed. Boissonade, 1829; Geoponica, ed. Beckh, 1985; Harvey, 1989; Kaplan, 1992; Tous and Ferguson, 1996; Bourbou et al., 2011; see the following paragraphs for a full discussion.

\begin{tabular}{llllll}
\hline Crop & $\begin{array}{l}\text { Key } \\
\text { season }\end{array}$ & $\begin{array}{l}\text { Weather } \\
\text { conditions } \\
\text { ensuring good } \\
\text { harvest }\end{array}$ & $\begin{array}{l}\text { Threatening } \\
\text { weather } \\
\text { conditions }\end{array}$ & Role in society & $\begin{array}{l}\text { Impact of } \\
\text { adverse climate } \\
\text { conditions }\end{array}$ \\
\hline
\end{tabular}




\begin{tabular}{|c|c|c|c|c|c|}
\hline $\begin{array}{l}\text { Cereals } \\
\text { (wheat, } \\
\text { barley) }\end{array}$ & $\begin{array}{l}\text { November- } \\
\text { April } \\
\text { (Aegean } \\
\text { and Black } \\
\text { Sea } \\
\text { regions); } \\
\text { May-June } \\
\text { (central } \\
\text { Anatolia) }\end{array}$ & $\begin{array}{l}\text { Regular, } \\
\text { adequate spring } \\
\text { rainfall; soil } \\
\text { moisture } \\
\text { recharge during } \\
\text { winter (snow } \\
\text { melt) in dry } \\
\text { farming areas }\end{array}$ & $\begin{array}{l}\text { Prolonged } \\
\text { winter, spring } \\
\text { drought, early } \\
\text { summer heat } \\
\text { stress }\end{array}$ & $\begin{array}{l}\text { Basis of diet (40- } \\
50 \% \text { annual } \\
\text { calorie intake) }\end{array}$ & $\begin{array}{l}\text { Subsistence } \\
\text { crisis, social } \\
\text { instability }\end{array}$ \\
\hline Vine & $\begin{array}{l}\text { April- } \\
\text { September }\end{array}$ & Sunny summers & $\begin{array}{l}\text { Spring hoar } \\
\text { frost; summer } \\
\text { heat; late } \\
\text { summer rain }\end{array}$ & $\begin{array}{l}\text { Wine widely } \\
\text { traded; local, } \\
\text { regional } \\
\text { specialisation in } \\
\text { vine cultivation }\end{array}$ & $\begin{array}{l}\text { Local- or } \\
\text { regional-scale } \\
\text { economic crisis }\end{array}$ \\
\hline Olive & $\begin{array}{l}\text { April- } \\
\text { December }\end{array}$ & $\begin{array}{l}\text { Dry climate; } \\
\text { adequate spring } \\
\text { rainfall }\end{array}$ & $\begin{array}{l}\text { Prolonged frost } \\
\text { in winter (below } \\
-10^{\circ} \mathrm{C} \text { ) }\end{array}$ & $\begin{array}{l}\text { Olive oil } \\
\text { consumption by } \\
\text { all strata of } \\
\text { society; local, } \\
\text { regional } \\
\text { specialisation }\end{array}$ & $\begin{array}{l}\text { Local- or } \\
\text { regional-scale } \\
\text { economic crisis }\end{array}$ \\
\hline
\end{tabular}

\subsection{Cereal cultivation}

The key cereals in Byzantine agriculture were wheat and barley, although rye and millet were also cultivated. Cereals were one of the major elements of the agricultural regime and any larger-scale expansion of rural settlement necessarily involved their cultivation (Stathakopoulos, 2004) as they provided 40-50\% of the annual calorific intake of a typical Byzantine diet (Kaplan, 1992, pp. 25-32; Bourbou et al., 2011). Poor cereal harvests - especially when repeated within a short period of time could lead to subsistence crises on a regional or even larger scale. In such contexts, the state would draw less tax income from agricultural produce and such cases were sometimes associated with social upheaval accompanying food shortage.

Byzantine textual sources emphasise the importance of regular rainfall from November until April for cereal farming, and in particular of the late autumn rains (Psellus, Peri georgikon, ed. Boissonade, 1829, and Geoponica, ed. Beckh, 1985, I 5; cf. Teall, 1971 on Geoponica). Cereal fields were usually harvested in June or July (Kaplan, 1992, pp. 56-61). Yields were dependent on adequate rain during the spring growing season as well on weather conditions during the sowing in autumn. Wet and 
warm conditions before the oncoming winter would be effective for the seed germination and good vernalisation (Geoponica, ed. Beckh, 1985,II 14).

\subsection{Vine and olive cultivation}

Wine was popular among all strata of Byzantine society, widely traded and probably the most attractive cash crop during the Middle Ages. Little is known in detail of the operation and daily management of such estates, although evidence from magnate wills, from later monastic archives, especially for the period from the eleventh century on, and occasional references to matters of estate management in letters give some indication (Frankopan 2009 and relevant sections in Laiou 2002 and Morrisson and Laiou 2007). Entire estates, villages or even small regions specialised in wine production (Harvey, 1989, pp. 146-147 and Kaplan, 1992, pp. 69-73). Representing only 5-10\% of the total calorific input, a bad grape harvest could not lead to a subsistence crisis. On a shorter time scale (i.e., 3-5 years), however, poor grape harvests could affect an estate owner, a farmer or a region that relied economically on wine production. Recurring poor harvests, over a longer period of time (i.e., 10 years) and over a wider region could lead to a significant transformation of the agricultural regime, pressure on the social structure of a region, and likely to economic decline. Byzantine farmers were fully aware of the importance of climatic conditions for the cultivation of vine, in particular of the role that sunshine in combination with moderate temperatures had in achieving a good harvest (e.g., Geoponica, ed. Beckh, 1895, V 4, VII 1). A major threat that could lead to a complete loss of the annual grape harvest was the occurrence of hoar frost late in the spring. Other factors that influenced harvest outcomes included the excessive summer heat and the late summer rain that affect grapes and consequently the quality of wine (Geoponica, ed. Beckh, 1895, V 36 and 43,3$)$.

Like wine, olive oil was an important element of the Byzantine diet, and it had some share in the total calorific input. It was also traded on a relatively large scale and estates or villages often specialised in olive cultivation (Lefort, 2002; Mitchell, 2005). According to documentary evidence, olives grow best 
in a dry climate (Geoponica, ed. Beckh, 1895, IX 3). Interestingly, information on unfavourable weather conditions for olive cultivation is found only in Byzantine narrative sources (Telelis, 2008), but not in the agronomic literature. A prolonged period of temperatures below $-10^{\circ} \mathrm{C}$ can, however, substantially damage olive trees (Tous and Ferguson, 1996). But it is likely that such conditions were not considered as a major threat to regions where the olive was grown, and that their perceived frequency was much lower than weather events that were dangerous to viticulture.

\subsection{Weather variability, agricultural output and tax income}

The tax income of the Byzantine state was directly linked to agricultural output on a medium-term basis (decades). Several taxes were calculated according to the size of households, or the number of animals owned by a taxpayer. However, the key source of the state's income was the land tax which was calculated on the basis of the soil quality and the type of cultivated crop (Harvey, 1989, pp. 102113 and Oikonomidès, 1996, pp. 42-121). In the ninth century AD, this tax provided the greater part of the state's income (Morrisson, 1991, Oikonomidès, 1996, pp. 24-41). A single year or a sequence of very bad years could result in difficulties for taxpayers and, consequently, social tensions and a reduction in fiscal income. The state sometimes acknowledged such unusually low annual or multiannual yields, and the resultant inability of the taxpayers to pay their dues, or even the malnutrition and hunger of the peasants. In such cases, substantial tax exemptions could be granted, such as during the great famine of AD 928 (Kaplan, 1992, pp. 461-462; Morris 1976). In addition, from the tenth century AD the state progressively became the largest secular estate owner and, along with the church, organised directly the cultivation of its own lands (Oikonomidès, 1991), thus becoming itself directly vulnerable to lower yields. 


\section{Evidence on the economic performance of Byzantium (AD 850-1300)}

The economic history of Byzantium during the MCA can be studied making use of a wide range of evidence (Fig. 1, Table III). Historical (textual) sources contain qualitative information about longterm changes of the economic situation. Quantitative data originate from archaeological and palaeoenvironmental research conducted on specific sites in the Balkans and Anatolia (Fig. 1). Archaeological field surveys and excavation data provide information on i) numbers and values of coins found on sites and ii) numbers of sites per period within a surveyed region. In this way, archaeology offers direct data on the changes in the intensity of monetary exchange that took place in the cities and in the density of settlements in the countryside.

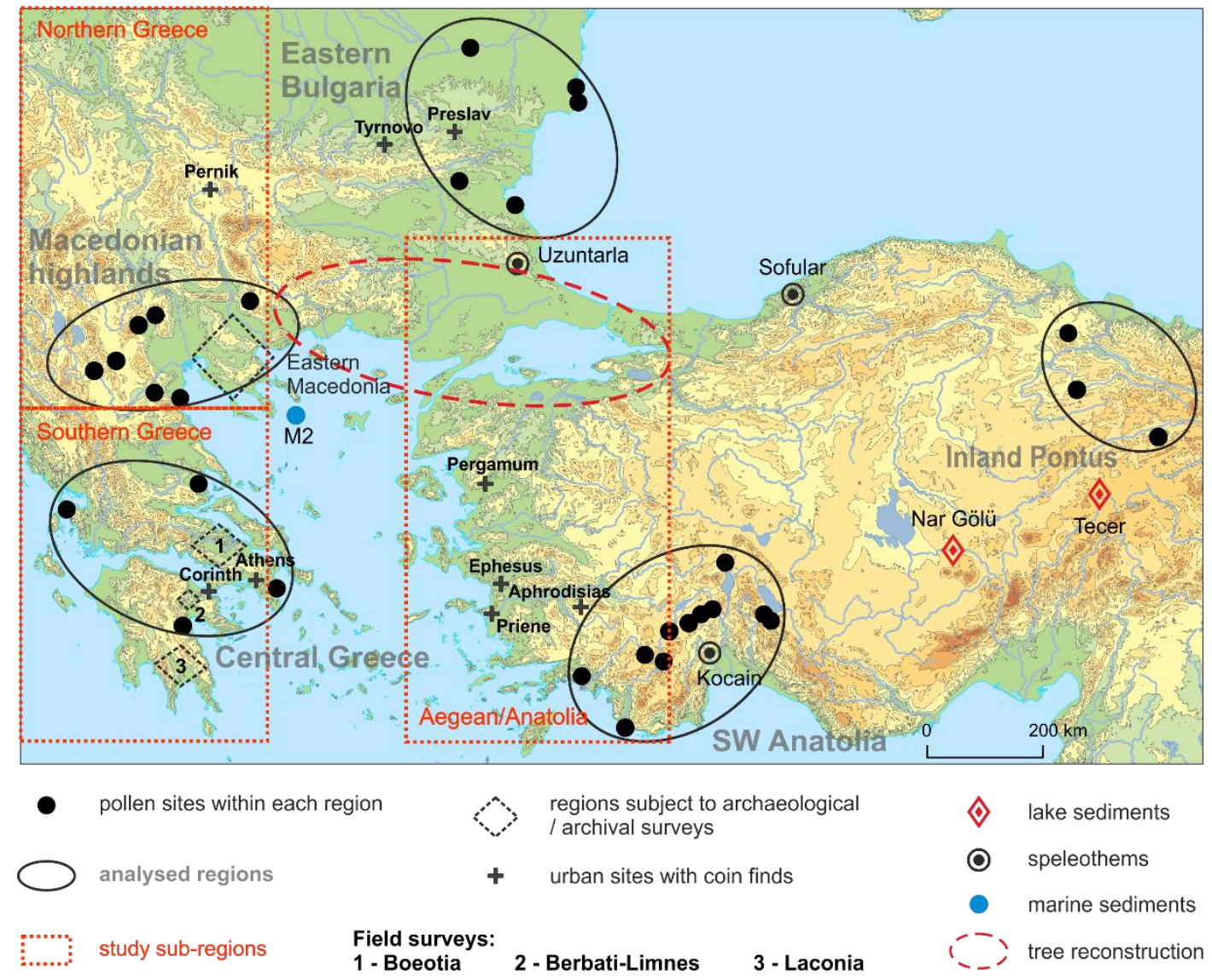

Fig. 1. Sites and regions providing evidence on the performance of the medieval Byzantine economy. Locations of proxy records, study sub-regions. Area considered for the climate models analysis. 
Table III. Types of evidence available for the study of Byzantium's economic performance

\begin{tabular}{|c|c|c|c|c|}
\hline Type of evidence & Phenomena recorded & $\begin{array}{l}\text { Economical } \\
\text { relation }\end{array}$ & $\begin{array}{l}\text { Character of } \\
\text { information }\end{array}$ & $\begin{array}{l}\text { Chronological } \\
\text { precision }\end{array}$ \\
\hline Historical - narrative & $\begin{array}{l}\text { taxation system, social } \\
\text { relations, long-term } \\
\text { economic situation }\end{array}$ & $\begin{array}{l}\text { usually } \\
\text { indirect }\end{array}$ & qualitative & $\begin{array}{l}\text { approximate, } \\
\text { long-term } \\
(100-300 \text { yrs) }\end{array}$ \\
\hline Historical - archival & $\begin{array}{l}\text { population, cultivated } \\
\text { lands, agricultural } \\
\text { production structure, } \\
\text { scale }\end{array}$ & $\begin{array}{l}\text { often } \\
\text { direct }\end{array}$ & $\begin{array}{l}\text { qualitative \& } \\
\text { quantitative }\end{array}$ & $\begin{array}{l}\text { ca. } 10-50 \text { yrs } \\
\text { when } \\
\text { quantified }\end{array}$ \\
\hline $\begin{array}{l}\text { Archaeological - } \\
\text { coin finds }\end{array}$ & $\begin{array}{l}\text { monetary circulation on a } \\
\text { given site/region }\end{array}$ & direct & quantitative & $\begin{array}{l}\text { regnal periods, } \\
\text { ca. } 10-40 \text { yrs }\end{array}$ \\
\hline $\begin{array}{l}\text { Archaeological - } \\
\text { sites numbers }\end{array}$ & $\begin{array}{l}\text { regional, settlement } \\
\text { intensity, population } \\
\text { levels (indirectly), } \\
\text { cultivation scale }\end{array}$ & $\begin{array}{l}\text { rather } \\
\text { indirect }\end{array}$ & quantitative & $100-300$ yrs \\
\hline $\begin{array}{l}\text { Palaeoenvironmental } \\
\text { - palynology }\end{array}$ & $\begin{array}{l}\text { regional, relative changes } \\
\text { of anthropogenic plants }\end{array}$ & direct & quantitative & $100-200$ yrs \\
\hline
\end{tabular}

Among the palaeoenvironmental evidence, pollen records from different parts of the medieval Byzantine world are the most important source of information about local and regional agricultural activity. Changes in the proportions of pollen of anthropogenic plants, such as cereals, vine, and olive, provide information about the vegetation structure of a given area in the past and thus can be used as some indication of the scale of the agricultural activity around a given site (Eastwood, 2006; Bottema and Woldring, 1990), in addition to the climate information that the pollen data also contain (e.g., Barboni et al., 2004, Brewer et al., 2007, Li et al., 2008, Luterbacher et al., 2012 and references therein and Kaniewski et al., 2013, 2014).

All these data provide information about phenomena within the medieval Byzantine economy (monetary exchange, demographic growth, agricultural activity), but they do this in different ways and, most importantly, with different temporal resolutions. Textual evidence on economic activity gives only a very approximate impression of the economic trends and, consequently, only longerterm developments can be considered. Coins are dated either by the regnal years or, at a much lower resolution, by the reigns of individual emperors. Such data has a temporal resolution of 
approximately 50 years, as is visible in Fig. 2 . Data on rural settlements are based on the chronologies of pottery that do not usually allow a temporal span of less than a century, and remain controversial (Vroom, 2005). Finally, the pollen data we use here are often characterised by a relatively low temporal resolution, except for the rare cases of annually-laminated sediments which can be directly compared with specific historical events (e.g., England et al., 2008). This is due to the rather limited number of radiocarbon dates and low sampling resolution in the case of most of the pollen profiles from our study area (Luterbacher et al., 2012 and references therein; Izdebski et al., 2015).

\subsection{Historical evidence: changes in the general economic situation}

Hendy $(1970 ; 1989)$ was the first who suggested that the eleventh-twelfth century constituted a climax in the economic history of Byzantium. Harvey (1989) further demonstrated the increase in the monetisation of the Byzantine economy during the tenth to the twelfth century. This development is also evident in the growing complexity of the monetary system and the new smaller denominations that facilitated the use of money also for everyday transactions and indicate clearly a governmental awareness of the market function of the coinage (Harvey, 1989, p. 89, Hendy, 1970, Morrisson, 1976, 1991, 2002). Harvey (1989) also argued that the changes in the way that tax was collected and the increase in the amount of collected taxes were possible only if the Byzantine economy was expanding (Harvey, 1989, pp. 90-102). Moreover, the Byzantine state in the period ca. AD 1000-ca. 1200 was relatively rich when compared to previous centuries (Morrisson, 1991). Finally, the period from the tenth to the twelfth and possibly even the fourteenth century was characterised by continuous demographic growth in the Byzantine Balkans and Anatolia (Harvey, 1989). Documents also suggest that the total cultivated area on these estates was steadily expanding throughout the tenth to twelfth century (Harvey, 1989, pp. 47-58). Harvey's hypotheses regarding the demographic history of Byzantium were supported by Lefort $(1985,1991)$ and his studies on Macedonia from the tenth to the fourteenth century. 


\subsection{Archaeological data: regional demographic and economic histories}

\subsubsection{On-site coin finds: the monetary circulation}

The analysis of the frequency of coins per year from securely-dateable archaeological contexts

(Metcalf, 1960 and Morisson, 1991, 2001, 2002) is considered to represent the intensity of monetary circulation that was taking place on a given site. The circulation period of each coin can be assumed to be around two to three decades and is based on the regnal years of the emperor who issued the coin (Morrisson, 1991, pp. 299-301). Furthermore, changes in the frequency of coin finds per year are one indicator of the degree of expansion and contraction in the local economy, and it is important to note that coin finds from archaeological or survey contexts are almost exclusively of the bronze coinage, i.e., the lowest denominations, those used in everyday transactions (Harvey, 1989, pp. 86-87). It is, therefore, possible to make temporal connections between on the one hand the expansion and contraction of monetary exchange in a given region based on the incidence of numismatic material from urban sites (Fig. 1), and on the other the political, social and potential climatic impacts. Fig. 2 presents the changes in monetary circulation in different parts of Byzantium. The intensity of monetary exchange increased from the ninth century in southern Greece and western Bulgaria, while a considerable delay is evident for western Anatolia (Fig. 2). A decrease in monetary circulation after AD 1081 is characteristic for almost the entire empire. The second half of the twelfth century is a period of renewed expansion of monetary exchange everywhere across the Byzantine world, whereas a period of substantial contraction starts after AD 1200. At the same time, eastern Bulgaria shows a contrasting positive trend in the thirteenth century (Fig. 2) and it forms the core of the flourishing Second Bulgarian empire (Ritter, 2013). A contraction of monetary circulation is observable on sites associated with the Byzantine economic exchange system, which underwent deep fragmentation after AD 1204 (Laiou and Morrisson, 2007, pp. 166-230). 


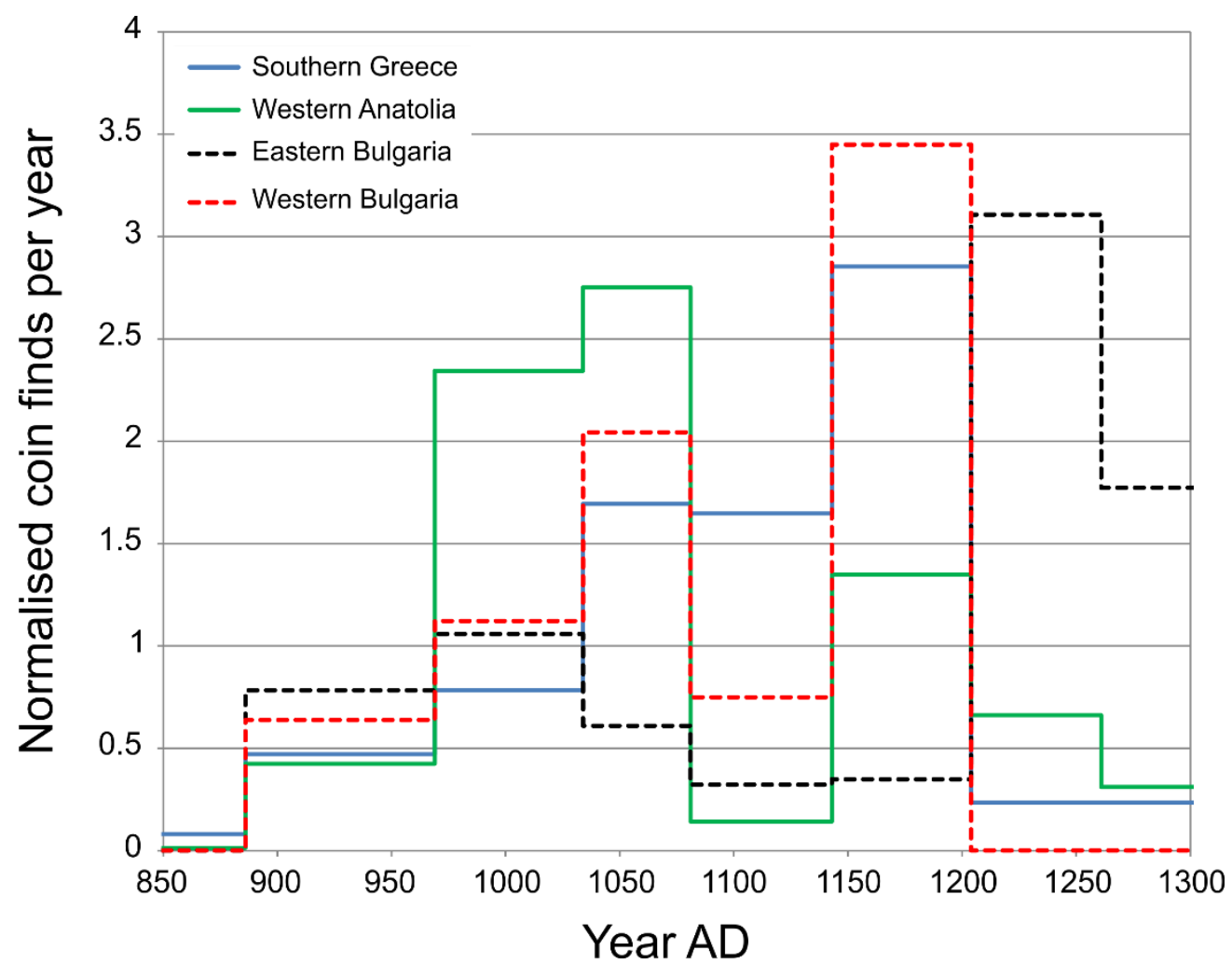

Fig. 2. Changes in monetary circulation on urban sites in selected regions of the Byzantine empire (AD 850-1300). The diagram presents regional averages of normalised frequencies of coin finds per year divided into periods determined by regnal years in excavations from each region. Southern Greece: Athens and Corinth (Morrisson, 1991); Western Anatolia: Aphrodisias, Ephesus, Pergamum and Priene (Morrisson, 1991, 2002: Fig. 6.1); Eastern Bulgaria: Preslav and Tyrnovo (Morrisson, 2002: Figs. 6.12, 6.13); Western Bulgaria: Pernik (Morrisson, 2002: Fig. 6.11). Values were transposed into positive numbers by subtracting the minimal average value in each region from the average values of all periods (the earliest period, AD 811-886, was characterised by the minimal value).

\subsubsection{Field surveys: changes in settlement intensity}

Regional surveys, in particular intensive ones that involve field walking, provide quantitative information about the intensity of rural settlement within the surveyed area. Such data more or less directly represent the number of sites that were inhabited within the surveyed region at a given period. Importantly, the periods vary from one survey to another, and the chronological precision of an archaeological survey depends on its ability to deal with the medieval ceramic finds, which provide the basis for the dating of site occupancy. Thus, there are several surveys which do not differentiate between the different sub-periods within the Middle Ages (such as early or late medieval periods, e.g., Davis et al., 1997 and Koukoulis, 1997) or where their period definitions are too broad to provide valuable information about the changes in the economy or demography of a particular region Byzantine society throughout its history (e.g., Tartaron et al., 2006). Only three 
surveys, two focused on the eastern Peloponnese (Hahn, 1996 and Armstrong, 2002) and one on the central Greek region of Boeotia (Vionis, 2008), provide quantitative information on how the regional rural settlement expanded and contracted throughout the middle Byzantine period (Fig. 3).

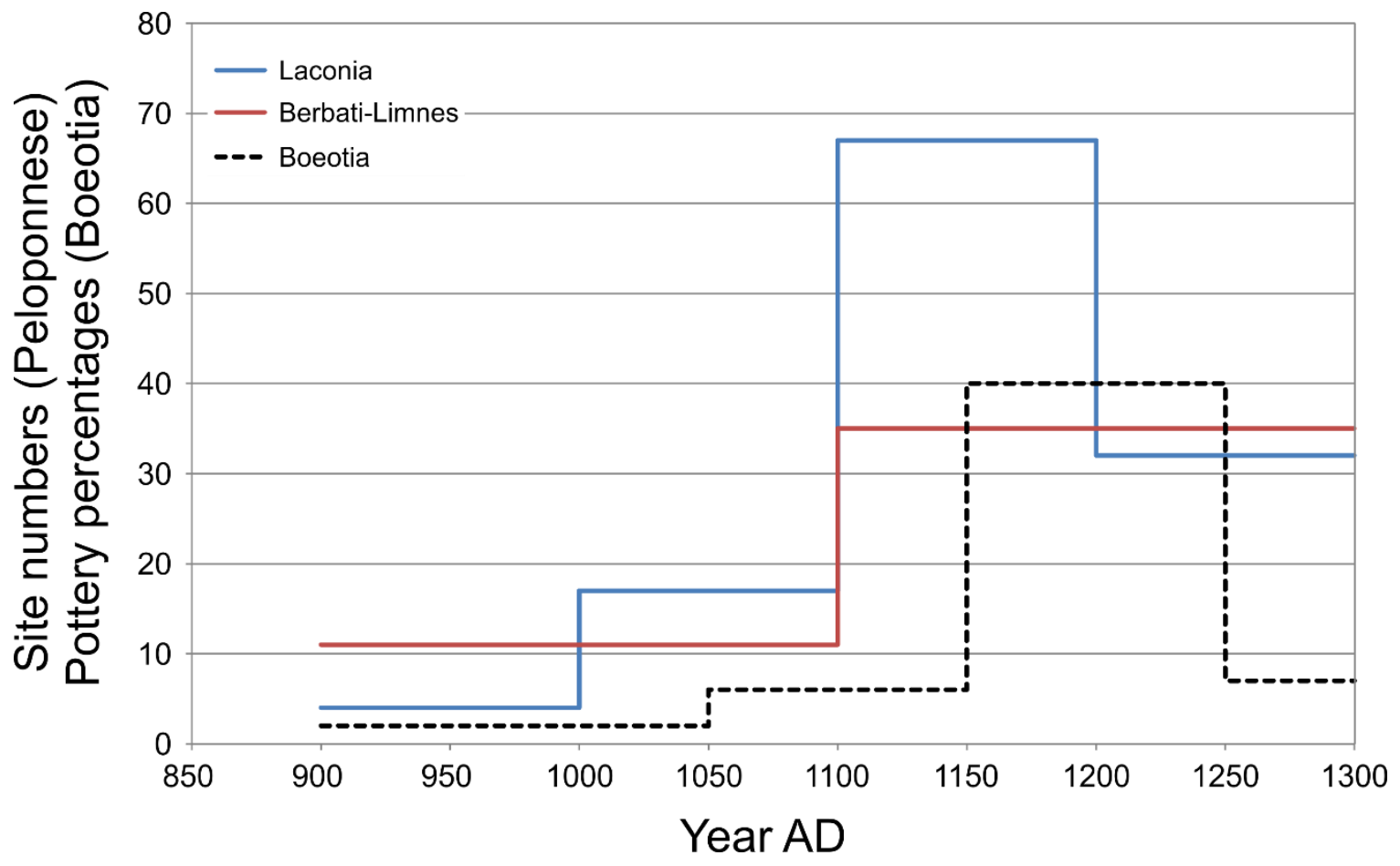

Fig. 3. Changes in settlement density in central and southern Greece/Peloponnese according to archaeological survey evidence. Increased site density reflects higher population numbers and more intensive land use in the surveyed area. Laconia: southeastern Peloponnese (Armstrong, 2002); Berbati-Limnes: northeastern Peloponnese (Hahn, 1996); Boeotia: central Greece (Vionis, 2008: Fig. 13).

The agricultural and settlement growth that started in the tenth, and possibly from the second half of the ninth century, continued without major interruption until it culminated in southern Greece/Peloponnese in the twelfth-thirteenth century. Interestingly, from the thirteenth century onwards the southern and northern parts of Greece seem to have experienced different trajectories of demographic and economic change (Figs. 3 and 4). The decline in southern Greece/Peloponnese appears to have started already in the thirteenth century (Fig. 3), whereas in eastern Macedonia, the population levels decreased only from the second half of the fourteenth century (Fig. 4).

Unfortunately, to date, there is no evidence of this kind from Anatolia. While the picture is slowly changing, archaeological surveys conducted in Turkey have often been either uninterested in the 
medieval Byzantine period or have used period definitions that are too broad to be informative (e.g., Vanhaverbeke and Waelkens, 2003 and Matthews et al., 2009). Nevertheless, there are a few studies suggesting that at least in some parts of Anatolia there did exist at least a flourishing middle Byzantine countryside. These data come from Galatia (central Anatolia, Anderson, 2008), Lycia (SW Anatolia, Kolb, 2008), and Milesia (Aegean coast, Müller-Wiener, 1961 and Lohmann, 1995).

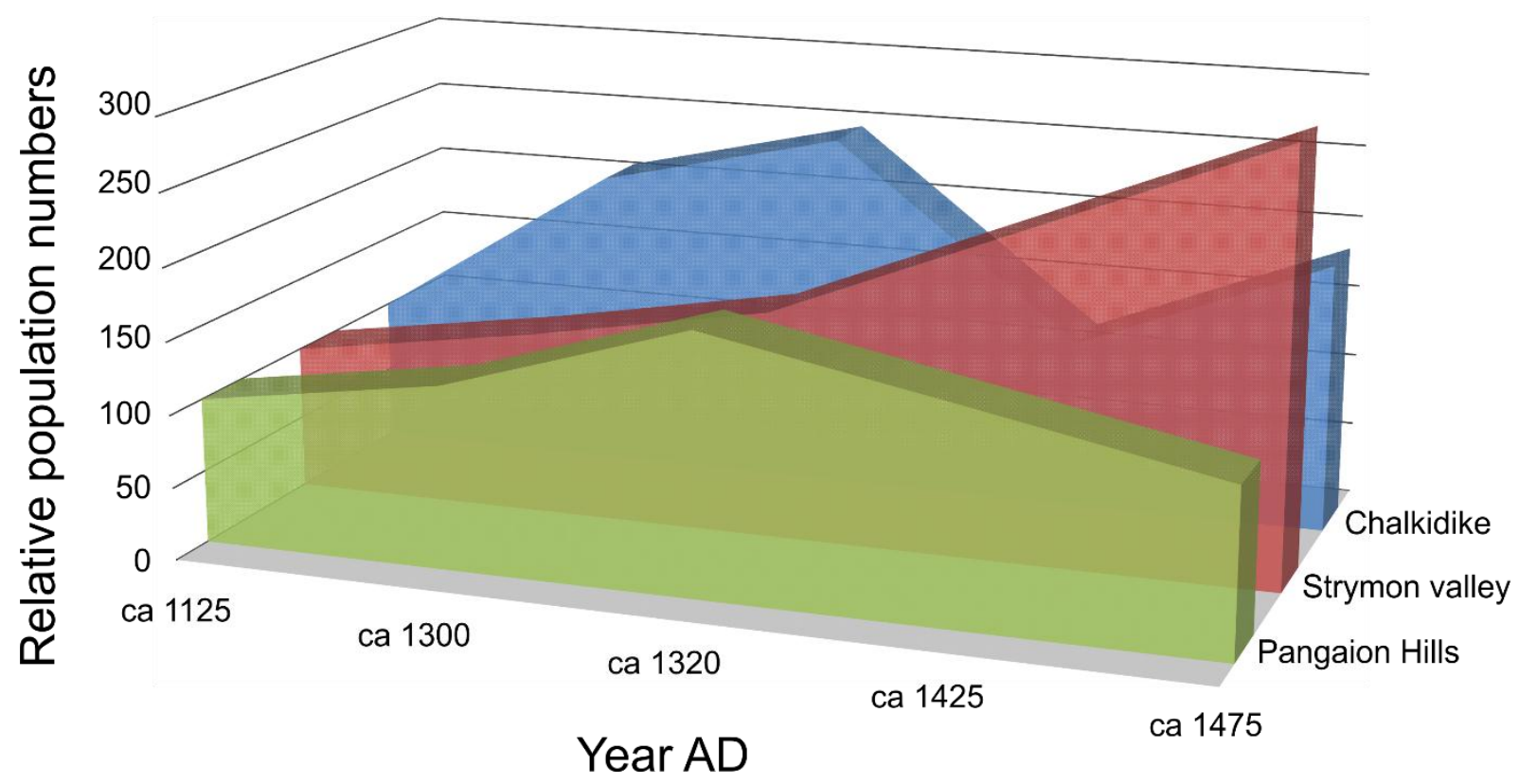

Fig. 4. Relative changes in population numbers in eastern Macedonia (Fig. 1) as compared to the early twelfth century population levels. Source: Lefort (1991: Tables 1, 2, 4).

\subsubsection{Palynological data: trends in agricultural production}

The use of palynological data for the study of economic and social Byzantine history has increasingly attracted the interest of historians of Byzantium (Haldon, 2007 and Izdebski, 2013). Pollen sites are located in most regions of the Byzantine world, in Greece, Bulgaria and in several parts of Anatolia

(Fig. 1). An important case study is the annually laminated Nar Gölü Lake that is located in central Anatolia (England et al., 2008). Up to the present, almost 40 sites in the Balkans and Anatolia have been discovered to have pollen samples that offer data pertaining to the Middle Ages (Izdebski, in press). Izdebski et al. (2015) synthesised this corpus of palynological evidence and provided regionally-weighted averages of the proportion of individual pollen taxa in the pollen sum of subsequent samples for selected regions in the Balkans and Anatolia (details on the applied method 
can be found in Izdebski et al., 2014). This approach permits the assessment of long-term changes in the vegetation structure of the Byzantine Balkans and Anatolia, from which we can infer trends in the agricultural activity in each of the regions studied. In this review, we present only the regional averages for cereal pollen from selected areas (Fig. 5). The curves presented here include Cerealiatype pollen as well as Triticum, Secale, Hordeum and Avena in the rare cases of those sites where their data distinguish between these pollen types. This means that, to some extent, our curve may also reflect pollen of wild grasses whose pollen grains are similar to those of cereals. Nevertheless, in the case of a comparatively complex socio-economic system such as that of the Byzantine empire this problem does not distort the relatively accurate picture of agricultural trends one can obtain from the regional pollen averages (Izdebski et al. 2014; 2015).

Based on the available data, agricultural expansion in the medieval Byzantine world has started in southwestern Anatolia around AD 850. At a slower and nearly synchronous pace the process began in Inland Pontus. In the Balkans, expansion of cereal cultivation is visible in central Greece and eastern Bulgaria after ca. AD 900, while in the highlands of western Macedonia (Fig. 5) the growth began as late as ca. AD 1100. Whereas agricultural growth in the Balkans continued until AD 1300, in Anatolia an agricultural decline set in after ca. AD 1050/1100. These dates are estimates, as they depend on the age-depth models of individual sites, which for the last two millennia are usually based on 2-3 radiocarbon dates (Izdebski et al., 2015; for further discussion of the chronological issues, see Izdebski et al., 2014). 


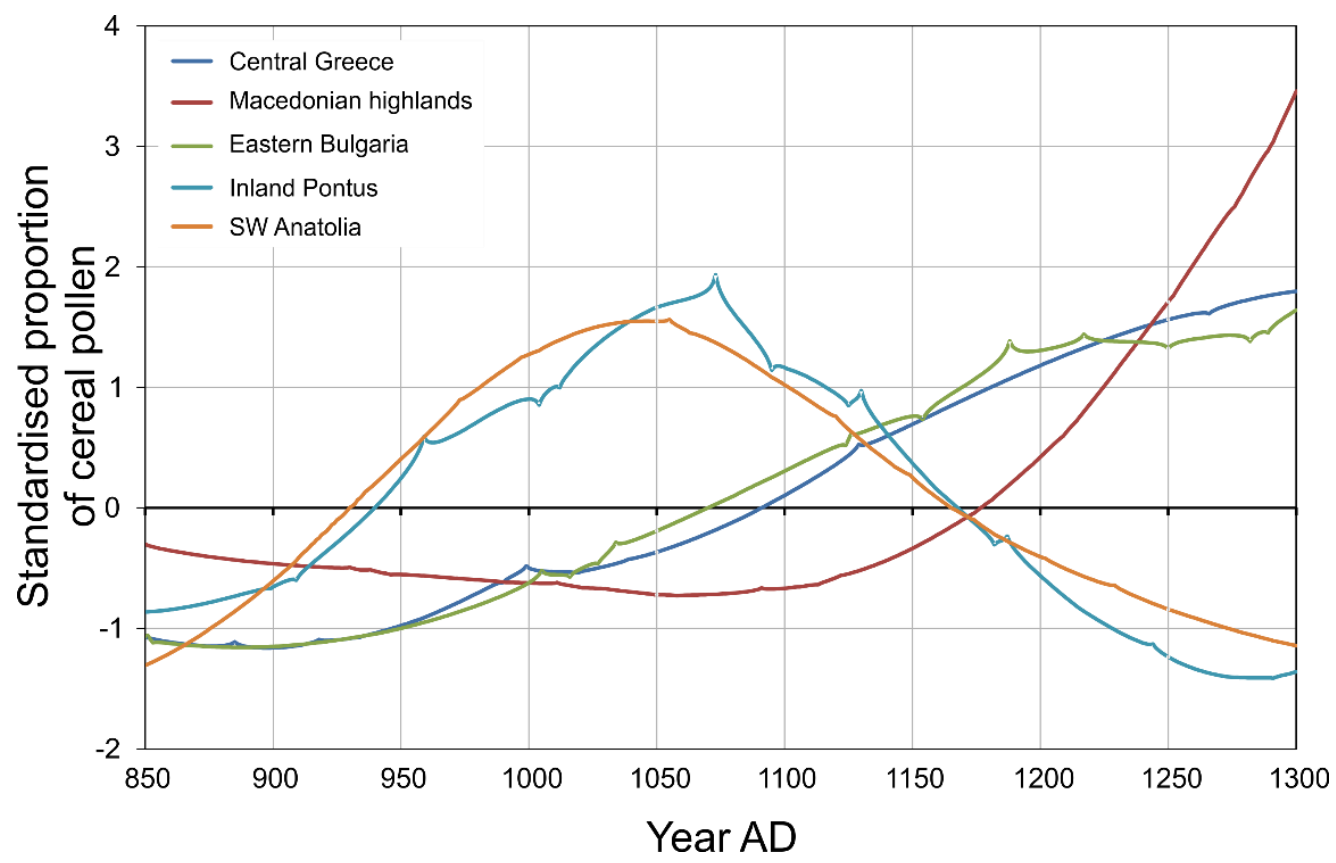

Fig. 5. Relative average proportions of cereal pollen in selected regions of the Balkans and Anatolia. Annual values have been standardised with respect to the period AD 800-1300. Source: Izdebski et al. (2015).

\section{Climate}

\subsection{Climatology of the Byzantine lands}

The Byzantine empire lies in a transitional zone, the greater Mediterranean Basin, between the deserts of North Africa and the Middle East, and central and northern Europe. The area is influenced by both subtropical and mid-latitude processes, as well as by large scale mechanisms acting upon the global climate system (Xoplaki et al., 2003 and Ulbrich et al., 2012 and references therein). In combination with the complex topography and the Mediterranean Sea, which is an important source of energy and moisture, this leads to the existence of a variety of climate zones across a relatively small area.

Two key seasons (October to March and April to September) relevant to the main Byzantine crops are analysed in this section (see Section 2). The extended winter (October to March) coincides with the Mediterranean wet season and especially for the eastern basin it contributes the greater part of the annual precipitation totals (from 50\% to over 90\%, Xoplaki et al., 2004 and references therein). The spatial pattern and standard deviation of temperature and precipitation over the medieval 
Byzantine lands are presented for extended winter and summer for the reference period 1951-1980,

together with their temporal variability since the mid-twentieth century (1951-2014), in Figs. 6 and 7, respectively. The two half-year seasonal temperature and precipitation trends have been assessed and tested for statistical significance using the non-parametric Theil-Sen estimator (Sen, 1968) and the Mann-Kendall test (Mann, 1945 and Kendall, 1975). The land-only E-OBS analyses v10.0 (Haylock et al., 2008, updated) on a $0.25^{\circ}$ horizontal spatial resolution is used. Anomalies are based on the reference period 1951-1980 for both variables.

(a)
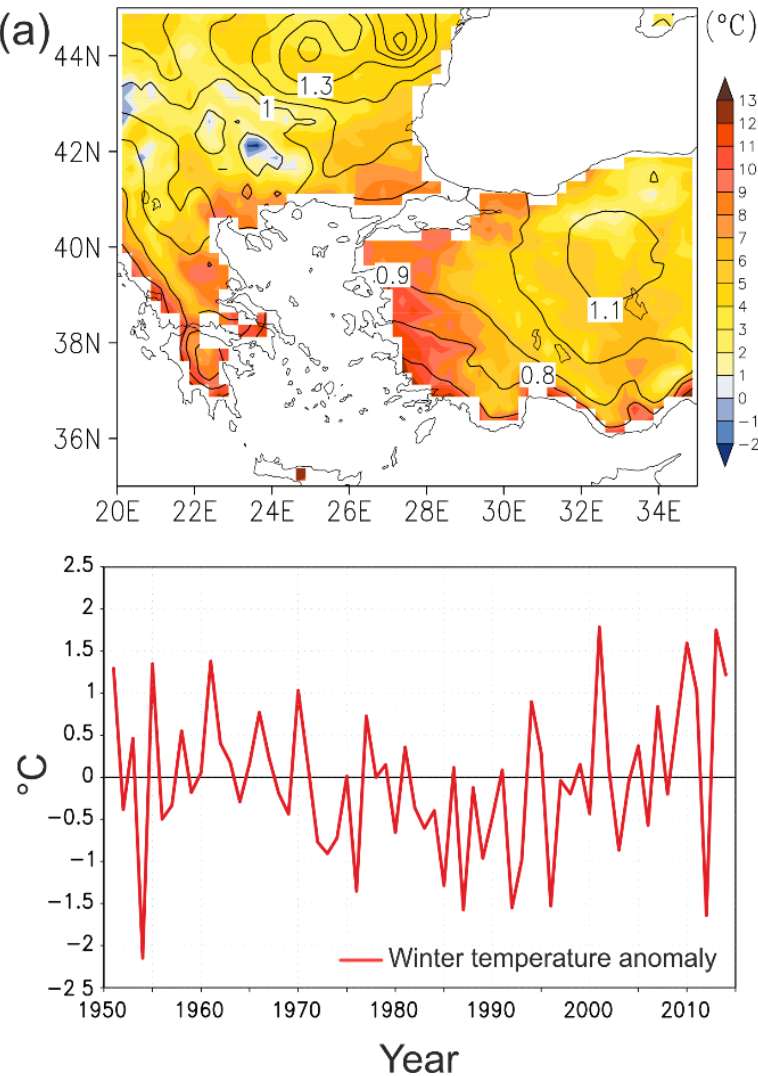

(b)
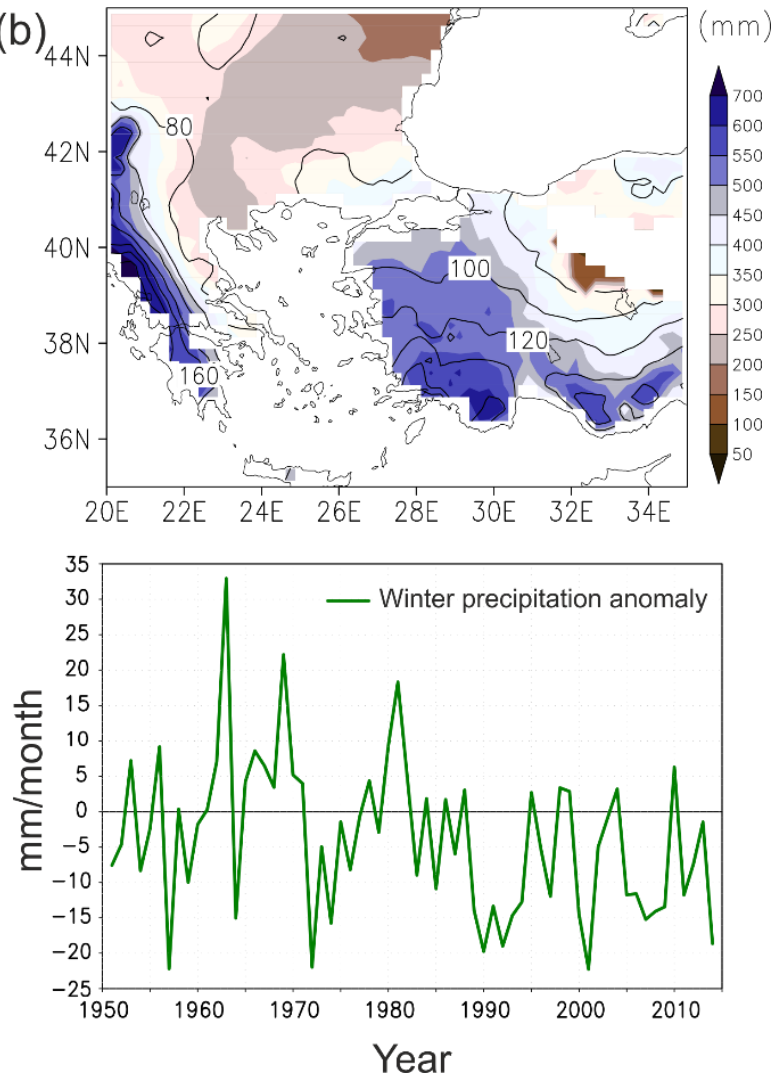

Fig. 6. Extended winter (October to March) mean climate in the medieval Byzantine lands. (a) Mean winter temperature field $\left({ }^{\circ} \mathrm{C}\right.$, over the period 1951-1980) and temporal changes during the period 1951-2014 (deviations from the 1951-1980 winter mean). (b) Mean winter precipitation amount field ( $\mathrm{mm}$, over the period 1951-1980) and temporal changes during 1951-2014 (deviations from the 1951-1980 winter mean). Black contours represent the standard deviation for each variable for the period 1951-1980. Data stem from daily E-OBS analyses v10.0 with $0.25^{\circ} \times 0.25^{\circ}$ spatial resolution (Haylock et al., 2008, updated). Anomalies (deviations) and standard deviation are calculated with respect to the 19511980 reference period.

A temperature gradient between coastal and inland areas characterises the study region (Fig. 6), with lower values $\left(3-9^{\circ} \mathrm{C}\right)$ being not only a function of the more northern latitude but also reflecting the complex orography (altitude). Mean extended winter temperatures below $3^{\circ} \mathrm{C}$ or even below 
freezing point are only found at higher altitudes. The largest variability in terms of standard deviation can be found over the northeastern part of the study area and central Turkey.

During the period 1951-2014, the extended winter temperature displays a relatively high variability with an upward trend (though not statistically significant) during the second half of the period studied. During the wet season (extended winter), the precipitation pattern (Fig. 6) shows a high spatial variability. The western coasts of Greece and Turkey receive more than half-meter rainfall amounts and show the highest temporal variability, while much lower totals are observed over the rainshadow areas, the leeward side of the mountains over eastern Greece and central Anatolia. High variability in October to March precipitation can be also seen during the recent past decades, in spite of the observed drying of the area (see also Xoplaki et al., 2004, Toreti, 2010 and Toreti et al., 2010). The decreasing trend of extended winter precipitation of $-10 \mathrm{~mm} /$ decade is statistically significant $(\mathrm{p}$ value less than 0.01).

The coastal areas-inland temperature gradient is evident also during the extended summer season (Fig. 7) and is strongly influenced by the orography. Mean temperatures range from $9^{\circ}$ to over $23^{\circ} \mathrm{C}$. April to September temperature generally shows smaller temporal variation compared with the cool season. The highest variability $\left({ }^{\circ} \mathrm{C}\right)$ is found again for the north-eastern part of the eastern Mediterranean. Statistically significant summer warming trends $\left(0.13^{\circ} \mathrm{C} /\right.$ decade $)$ over the last decades (Fig. 7), as well as temperature extremes and heat waves have been reported for the area (Kuglitsch et al., 2010 and Ulbrich et al., 2012). It should, however, be noted that the time series has a change point in 1983. Lower rainfall amounts characterise the warm season (Fig. 7), as well as a smaller temporal variability. During the warmest months (June to August), precipitation amounts largely reflect convective activity connected with thunderstorms. The temperature and precipitation patterns during both extended winter and summer show high spatial and temporal variability, which is characteristic for the area and thus suggest the complexity of the impacts that might be connected to changes in climate conditions. 
(a)
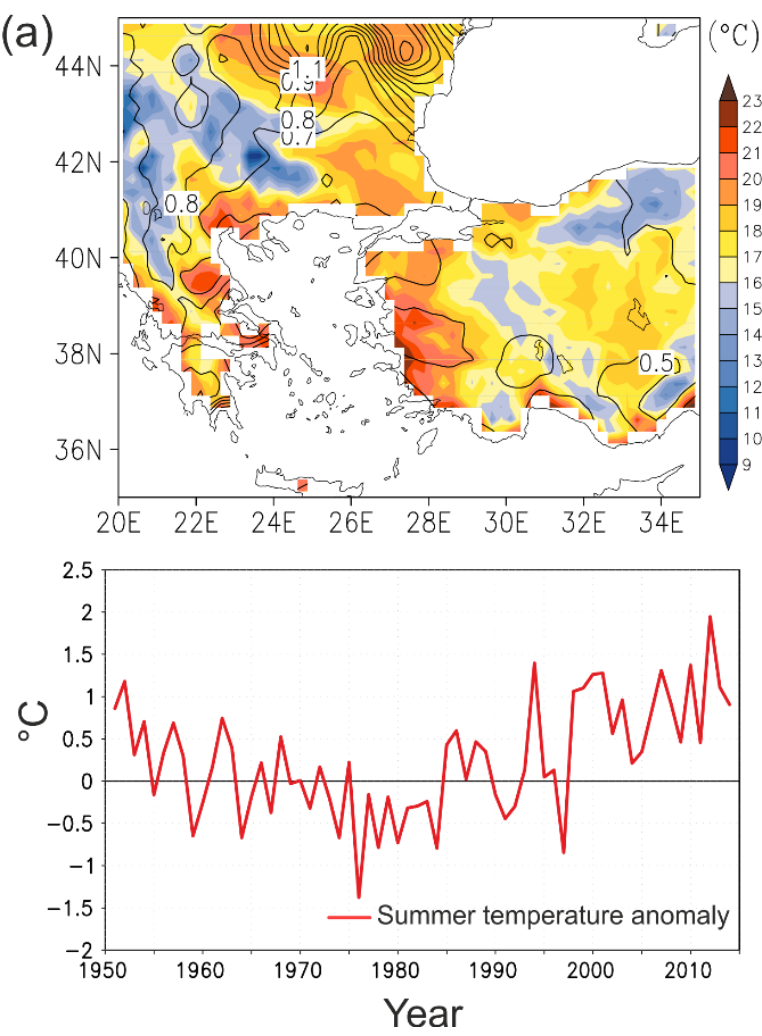

(b)
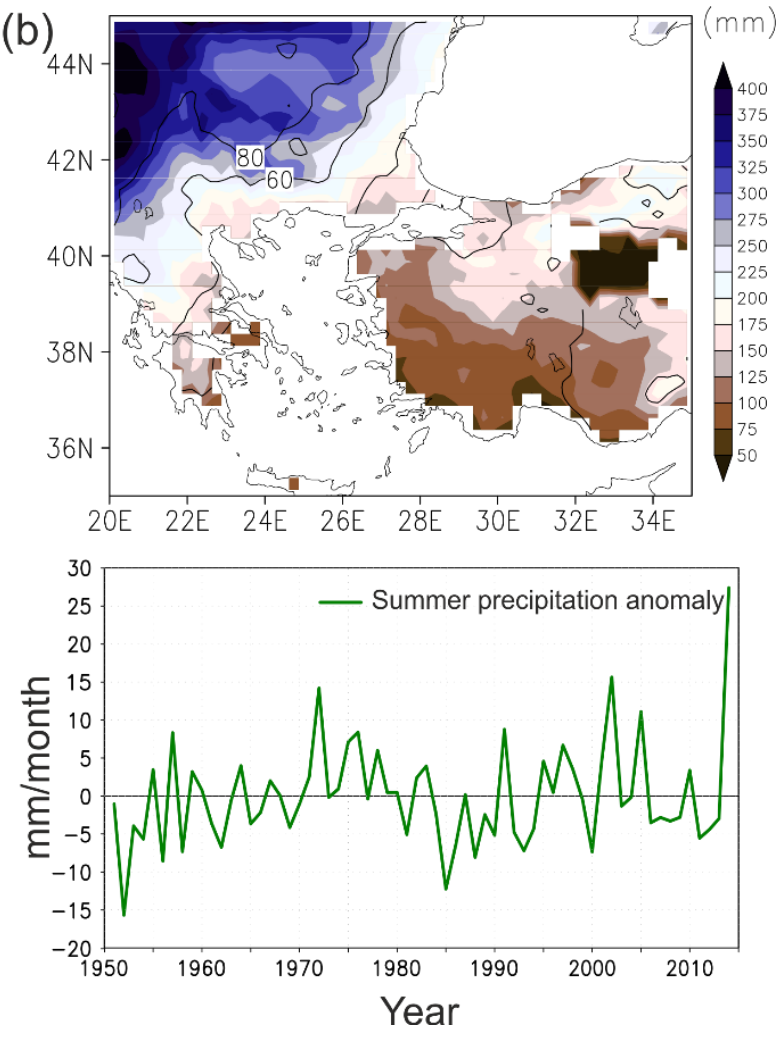

Fig. 7. As Fig.6 but for extended summer April to September.

\subsection{Palaeoclimate evidence for the medieval Byzantine region}

\subsubsection{Documentary, textual evidence}

Literary palaeoclimatic evidence from Byzantine texts remained rather unexplored for palaeoclimate research until the early 2000s (Telelis, 2004). Early works of "weather compilations" such as Hennig (1904), Easton (1928) and Weikinn (1958) did, however, include citations of accounts from some scattered Byzantine sources. But the need for a more comprehensive and systematic collection and analysis of information from Byzantine texts that could be relevant to climate in the past was emphasised by Croke (1990) as well as Chrysos (Telelis and Chrysos, 1992).

Telelis $(2000,2004,2005$ and 2008) presented a catalogue of textual palaeoclimate evidence derived from a wide variety of Byzantine sources, along with a detailed analysis of the methodological issues accompanying the use of such data. The advantages of these data are their high temporal resolution, the disentanglement of the temperature and precipitation, the coverage of all months of the year, and the high sensitivity to anomalies and natural hazards (Xoplaki et al., 2001). However, descriptive 
textual proxy data are usually discontinuous and heterogeneous, while various socio-cultural parameters may affect the perception of the observers and add a bias to the inclusion or exclusion of climatological information in the texts (Pfister et al., 1994, Brázdil et al., 2005 and Telelis, 2005, 2008). Furthermore, despite the wealth of the Byzantine literary tradition, climate-related accounts from Byzantine sources are rare (Telelis, 2008). Both the narrative content of palaeoclimate information, and its qualitative character do not allow the application of sophisticated statistical methods or the deduction of monthly indices of temperature/rainfall (e.g., Brázdil et al., 2005 and references therein) for medieval palaeoclimatic reconstructions (Telelis, 2008).

The data collection by Telelis $(2004,2008)$ is presented with a spatial distribution of each 50 year sub-period within the MCA. Fig. 8 shows the historical-climatological information from the Byzantine sources with monthly, seasonal and annual resolution for the corresponding locations and years. Information with a higher temporal resolution is disregarded, while conventional seasons (winter: December to February, spring: March to May, summer: June to August, autumn: October to November) are used. Most of the information corresponds to extreme climatic conditions, with few exceptions referring to "normal" or "mild" conditions. Furthermore, a higher concentration of the Byzantine sources is evident for Constantinople and the adjacent areas.

Most of the historical-climatological information from Byzantine sources reports a higher frequency of cold or extremely cold months / seasons for the periods AD 901-950, AD 1051-1100 and AD 12511300. Very warm events are rare in the collected data, with two records for each of the periods of $A D$ 851-900 and AD 951-1000. A larger number of rainy periods is reported for AD 951-1000 and AD 1051-1100, while a higher frequency of drought events are found during AD 1001-1050 and AD 10511100. A sequence of drought periods is reported for Constantinople and adjacent areas in AD 10251040 (Fig. 8). 

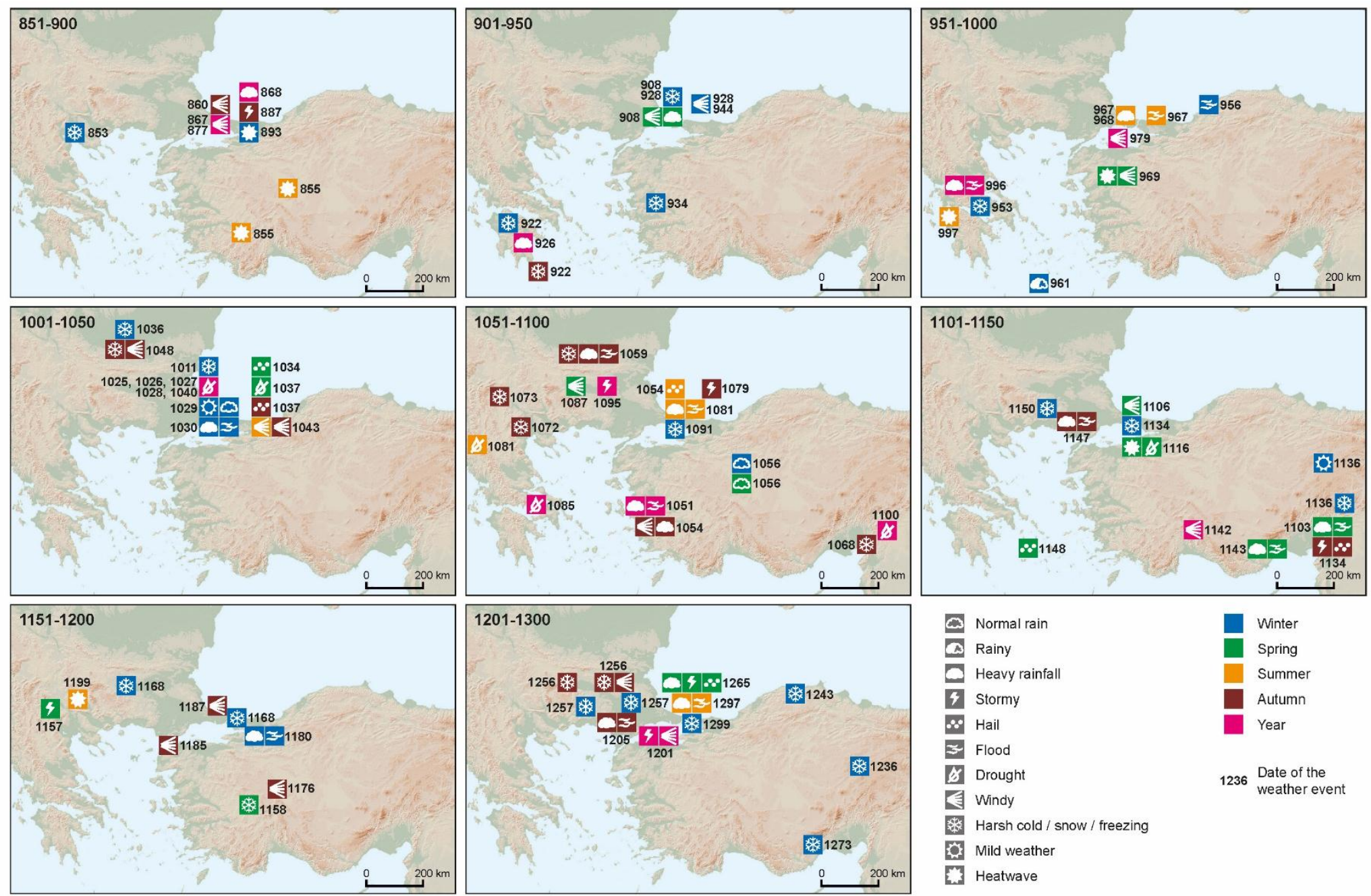

Normal rain
Rainy
Heavy rainfall
Stormy
Hail
Hindy
Hild weather
Heatwave

Fig. 8. Spatial distribution of documentary/textual historical-climatological data from Byzantine sources collected by Telelis (2000, 2008). Each plot corresponds to a 50-year period, except for the last MCA century, AD 1201-1300, due to information availability. Events with monthly, seasonal and annual duration are presented. The symbols background colours denote their temporal resolution. 


\subsubsection{Natural proxies}

The number of records providing detailed information on climatic fluctuations during the period ca. AD 850-1300 in the eastern Mediterranean is small (Fig. 1). Precisely-dated and highly-resolved $(<10$ years) records are needed to identify key regional patterns of climatic anomalies during medieval times and their differences to the twentieth century (Diaz et al., 2011, ; Euro_Med Consortium, 2015). Moreover, high spatially and temporally resolved multi-proxies are required to constrain the temporal and spatial variability of the medieval climate. Furthermore, multi-proxies in combination with model simulations allow the establishment of links between climate variability and societal changes in Byzantium.

A high resolution sediment multicore M2, retrieved in 2010 from the northern Aegean Sea (Athos basin, $40^{\circ} 05.15^{\prime} \mathrm{N}, 24^{\circ} 32.68^{\prime} \mathrm{E}$, Fig. 1) provides detailed information on annual sea surface temperatures (SSTs, Fig. 9; Gogou et al., this volume). SSTs show an increase (up to $18.5^{\circ} \mathrm{C}$ ) from the beginning of the MCA until AD 900. A negative shift in SST values is observed around AD 1050 to 1100 (of $\sim 0.4^{\circ} \mathrm{C}$ ) that could be associated with cool spells (Gogou et al. this volume). Tree rings from the Aegean (Griggs et al., 2007; Fig. 9) provide the most precisely-dated quantitative records of annually resolved May-June precipitation reconstructions for north-eastern Greece and northwestern Turkey $\left(39-42^{\circ} \mathrm{N}, 22-37^{\circ} \mathrm{E}\right)$. They show characteristic changes in late spring-early summer precipitation. Higher precipitation variability is reported between AD 1100 and 1200 with wetter conditions in the first half of the twelfth century followed by drier conditions after AD 1150 (Griggs et al., 2007; Fig. 9). These findings are in agreement with recent tree ring based summer PDSI reconstructions by Cook et al. (2015a) and Cook et al. (2015b).

Three Uranium-series dated stalagmite stable isotope records from Uzuntarla Cave (Thrace, $41^{\circ} 35^{\prime}$ $\mathrm{N}, 27^{\circ} 56^{\prime} \mathrm{E}$ ), Sofular Cave (Paphlagonia, $41^{\circ} 25^{\prime} \mathrm{N}, 31^{\circ} 57^{\prime} \mathrm{E}$ ) and Kocain Cave (Lycia, $37^{\circ} 13^{\prime} \mathrm{N}, 30^{\circ}$ 42' E, Fig. 1) display marked variations in their $\delta^{13} \mathrm{C}$-profiles, which are interpreted to reflect variations in effective moisture and consequently precipitation (Göktürk et al., 2011). However, all 
stalagmite isotope profiles show a markedly different pattern, as the caves are located in different climatic zones. Uzuntarla Cave is located in the temperate Marmara transition zone (Mediterranean to Black Sea), Sofular Cave lies in the Black Sea and Kocain Cave in the Mediterranean climatic zone (climatic zones as defined by Türkeş, 1996). Negative $\delta^{13} \mathrm{C}$ values of around $-10.6 \%$ o (VPDB) from Uzuntarla Cave indicate a rather long and fairly stable period lasting from around AD 800 to 1100 of enhanced precipitation and higher effective moisture. The rather abrupt increase in $\delta^{13} \mathrm{C}$ values between $A D 1100$ and 1230 suggests a drop in precipitation. The Sofular Cave $\delta^{13} \mathrm{C}$ record, however, suggests an increase in local precipitation at around $A D 1000$ and high effective moisture until at least AD 1300, whereas a fairly short-lived period of slightly lower precipitation (more positive $\delta^{13} \mathrm{C}$ values) is centred at around AD 1200. The Kocain Cave $\delta^{13} \mathrm{C}$ record from south-western Turkey is considered to reflect variations in snow cover and more effective recharge of the aquifer above the cave at times of enhanced snow cover (Göktürk, 2011). More negative $\delta^{13} \mathrm{C}$ values indicate increased snow cover during cold winters. In contrast to the Uzuntarla and Sofular Cave records, distinct longterm trends are not evident in the Kocain Cave $\delta^{13} \mathrm{C}$ record. Very low $\delta^{13} \mathrm{C}$ values occur between ca. AD 1000 and ca. AD 1100 and suggest that this period was characterised by rather cold winters and enhanced snow cover. Interestingly, these rather colder winter temperatures in the Kocain Cave record are contemporaneous with a drop of around $0.4{ }^{\circ} \mathrm{C}$ in north Aegean SSTs (M2).

Two lake records from central Anatolia, the Nar Gölü oxygen isotope record $\left(\delta^{18} \mathrm{O}\right)$ (Jones et al., 2006) and the Tecer Lake Aragonite record (Kuzucuoğlu et al., 2011), reflect variations in the precipitation/evaporation balance of the lakes and are therefore influenced by the amount of precipitation in winter and spring and evaporation rates in summer. Between ca. AD 850 and ca. AD 1000 both lake records suggest either a steady reduction in evaporation rates or an increase in precipitation, although the latter factor appears to be more likely. The almost annually-resolved Nar Gölü $\delta^{18} \mathrm{O}$ record shows evidence for increased humidity (more negative $\delta^{18} \mathrm{O}$ values) until at least $A D$ 1100. In the twelfth century, increasing Nar Gölü $\delta^{18} \mathrm{O}$ values indicate increasing aridification, a trend 
that is also evident in the Sofular Cave and Uzuntarla Cave $\delta^{13} \mathrm{C}$ records (Fig. 9). Taken together, the palaeoclimate records show evidence for rather stable and wet climatic conditions between AD 900 and AD 1100 (Uzuntarla Cave, Sofular Cave, Nar Gölü Lake) and likely a series of cold winters between AD 1000 and AD 1100 (Kocain Cave and M2 north Aegean SSTs).

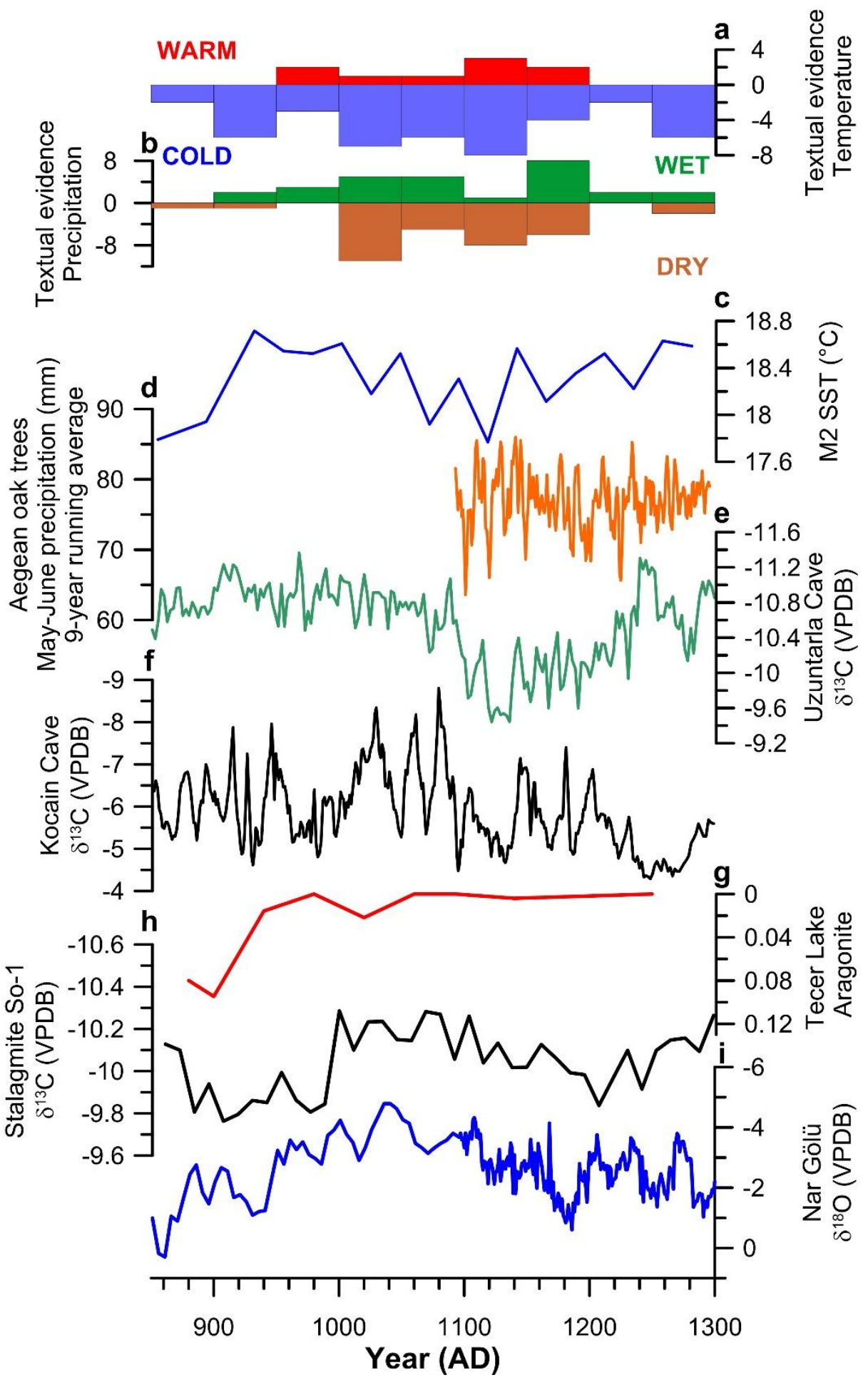


Fig. 9. Proxy records from the medieval Byzantine lands. (a,b) textual evidence (warm/cold, dry/wet seasons, see Section 4.2.1, Telelis, 2008); (c) M2 SST, high resolution palaeoceanographic alkenone sea surface temperature (SST, ${ }^{\circ} \mathrm{C}$ ) reconstruction from the northern Aegean Sea (Gogou et al., this volume); (d) Aegean oak trees May-June precipitation for NE Greece and NW Turkey (9-year filter, Griggs et al., 2007); (e) Uzuntarla Cave: effective moisture biased towards winter and spring precipitation in Marmara region (Göktürk et al., 2011); (f) Kocain Cave: effective moisture related to winter and spring precipitation in south-western Turkey (Göktürk et al., 2011); (g) Tecer Lake: aragonite precipitation, precipitation / evaporation balance in south-eastern Turkey (Kuzucuoğlu et al., 2011); (h) Sofular Cave: effective moisture in the Black Sea area (Göktürk et al., 2011); (i) Nar Gölü: water, precipitation / evaporation balance in southwestern Turkey (Jones et al., 2006).

\subsection{The middle Byzantine climate simulated by climate models}

\subsubsection{Setup of climate model simulations}

Three model simulations were selected for comparisons with textual and natural proxy-based climatic evidence. i) Two experiments from the Coupled Model Intercomparison Project Phase 5 (CMIP5, Taylor et al., 2012), starting in AD 850, namely the CCSM4 and MPI-ESM-P simulations. Among the variety of CMIP5 simulations these experiments have the highest spatial horizontal resolution. The simulations were carried out with changes in external forcing parameters (i.e., volcanic eruptions, solar variations, orbital, and anthropogenic changes in the composition of the atmosphere and land use change; IPCC, 2013) following the Paleoclimate Model Intercomparison Project Phase III (PMIP3) protocol (Schmidt et al., 2012). ii) The ECHO-G-MM5 regional simulation encompasses the European realm with a $45 \mathrm{~km}$ grid spacing. Such spatial resolution allows the investigation of climatic fluctuations on a regional scale, including changes in the hydrological cycle. ECHO-G-MM5 is forced with a 2000-year long simulation with an earlier version of a comprehensive GCM.

The external forcing parameters of the CCSM4 and MPI-ESM-P are related to transient changes in orbital, solar, volcanic, greenhouse gas and land use forcing (see Schmidt et al., 2012 for a detailed description). Both simulations used the solar irradiance reconstruction of Vieira et al. (2011). This reconstruction presents a difference of $0.1 \%$ between present day and the Maunder Minimum (AD 1645-1715), a period that is well known for the scarcity of sunspots and thus less intense solar radiative output (Maunder, 1922 and Eddy, 1976). Regarding the implementation of the volcanic forcing, CCSM4 used the Gao et al. (2008) volcanic forcing data and MPI-ESM-P used the Crowley and 
Unterman (2013) volcanic reconstruction. Land use changes are prescribed after Pongratz et al.

(2008) for the time between AD 850 and AD 1850.

The CCSM4 model consists of an atmospheric component CAM4 with 26 vertical levels and a horizontal resolution of $0.9^{\circ} \times 1.25^{\circ}$ coupled with the ocean model POP with a variable horizontal resolution of $1.1^{\circ}$ increasing from $0.54^{\circ}$ at $33^{\circ} \mathrm{N} / \mathrm{S}$ towards $0.27^{\circ}$ at the equator and 60 vertical levels. The land model used is the CLM4. A comprehensive description of the simulation of the last millennium can be found in Landrum et al. (2013) including a detailed description of the model setup. For this model only one realisation is available, however, the advantage of the simulation is its extraordinary high spatial resolution for a global Earth System Model, which corresponds to $80 \mathrm{~km}$ longitude x $140 \mathrm{~km}$ latitude over the Mediterranean region.

The MPI-ESM-P model consists of the atmospheric model ECHAM6 with horizontal resolution $1.85^{\circ} \times 1.85^{\circ}$ that is approximately $160 \mathrm{~km}$ longitude $\times 200 \mathrm{~km}$ latitude over the Mediterranean region and 47 levels. The model is coupled with the ocean model MPI-OM (bi-polar curvilinear grid: $1.5^{\circ}$ horizontal resolution with 40 levels). The vegetation model JSBACH is also used, to take into account prescribed changes in land use. The model and experiment setup are discussed in greater detail in Giorgetta et al. (2013). The MPI-ESM-P r1, r2 and r3 realisations are used in this review. These realisations have different initial oceanic conditions in the year AD 850. The $r 2$ and $r 3$ realisations were also carried out with slightly different versions of the volcanic data set and with a correction of the ozone annual cycle (Jungclaus et al., 2014). For the majority of the results, the $r 1$ simulation is shown. The $r 2$ and $r 3$ realisations are mainly used to show differences that occur in the temporal evolution of the climate due to the differences in the initial conditions of the model runs in year AD 850.

The ECHO-G-MM5 regional simulation extends back to $1 \mathrm{AD}$ and it was forced by an earlier simulation carried out with the comprehensive atmosphere-ocean general circulation model 
(AOGCM) ECHO-G. ECHO-G consists of the atmospheric model ECHAM4 (horizontal resolution T30:

$3.75^{\circ} \times 3.75^{\circ}$ with 19 vertical levels $)$ coupled with the ocean model HOPE-G $\left(2.8^{\circ} \times 2.8^{\circ}\right.$ spatial resolution including increased horizontal resolution over the tropics down to $0.5^{\circ}$ at the equator and 20 vertical levels). ECHO-G-MM5 is flux adjusted to prevent climate drift (AOGCMs could drift into some unrealistic climate state - spurious long-term changes in general circulation models that are unrelated to either changes in external forcing or internal variability, Sen Gupta et al., 2013). The implemented external forcings are restricted to orbital, solar and GHG forcing, because no volcanic reconstruction was available prior to $A D 850$. Also the scaling of the solar constant is comparatively high with $0.3 \%$ difference in solar activity between present day and the Maunder Minimum and thus corresponds to scalings used in the late 1990s and early 2000s (Crowley, 2000). The more realistic representation of the topography and the complexity of the coastline, which is important for the eastern Mediterranean, clearly suggests the use of the ECHO-G MM5 for the area and enables the investigation of changes at the regional scale. Furthermore, due to the increased horizontal and vertical resolution, the processes related to the hydrological cycle, i.e. precipitation, evaporation and near-surface humidity variability are represented more realistically compared to a coarser resolved GCM. A more detailed description of the ECHO-G-MM5 model setup and the ECHO-G model setup can be found in Gómez-Navarro et al. (2013) and Wagner et al. (2007), respectively.

The temporal focus is on the middle Byzantine period and somewhat afterwards (ca. AD 850-1300), and the model results are presented with respect to the IPCC AR5 reference period AD 1500-1850. The selected seasons of extended winter (October to March) and extended summer (April to September) (see also Section 2) are used for the model data analysis. In addition to the full domain $\left(20^{\circ}-35^{\circ} \mathrm{E}, 35^{\circ}-45^{\circ} \mathrm{N}, \mathrm{Fig} .1\right)$, three sub-regions were also selected to study potential regional differences within the Eastern Mediterranean area. These regions are: Northern Greece $\left(40^{\circ}-45^{\circ} \mathrm{N}\right.$, $\left.20^{\circ}-24^{\circ} \mathrm{E}\right)$, Southern Greece $\left(36^{\circ}-40^{\circ} \mathrm{N}, 20^{\circ}-24^{\circ} \mathrm{E}\right)$, Aegean/Anatolia $\left(36^{\circ}-42^{\circ} \mathrm{N}, 26^{\circ}-30^{\circ} \mathrm{E}\right)$ (Fig.1). 
The model simulations are used as the basis for the calculation of near-surface temperature,

precipitation and soil moisture temporal variability (Figs. 10-12) in the medieval eastern

Mediterranean. Spatially resolved fields (Figs. 15) are also provided in order to investigate potential local changes or climate transitions between different regions.
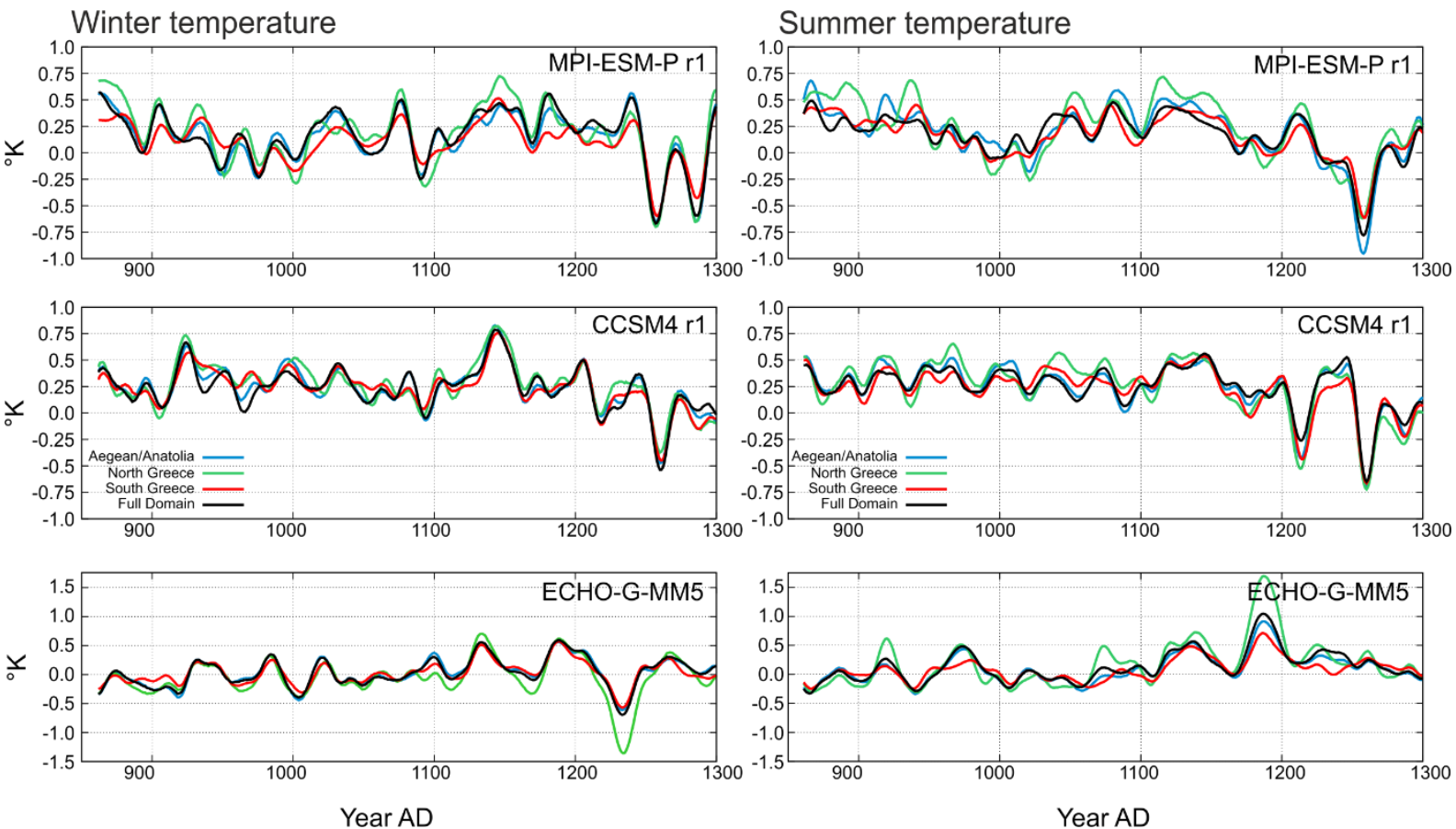

Fig. 10: Extended winter (October - March) and extended summer (April - September) temperature anomalies for different model simulations and different regions in the eastern Mediterranean during MCA. Upper panel: MPI-ESM-P; Middle panel: CCSM4; Lower panel: ECHO-G-MM5. Anomalies (in ${ }^{\circ} \mathrm{K}$ ) are calculated with respect to the reference period AD 1500-1850 (i.e., deviations from the AD 1500-1850 seasonal mean).

\subsubsection{Hypotheses on socio-politically unstable periods and climate model simulations}

This section presents and analyses a few hypotheses on potential links between climatic and societal changes that took place during specific periods in Byzantium. The analysis encompasses the entire study area together with sub-regional findings (Figs. 1, 10-12), as well as comparisons with model simulations presented in the sub-sections of 4.3.2. For precipitation, in particular, because of the higher spatial variability of the hydrological changes (see also Section 4.1), the analysis focuses on the three sub-regions (Northern Greece, Southern Greece and Aegean/Anatolia, Fig. 1). 


\subsubsection{Temperature variability during the MCA over the Byzantine lands}

Strong similarities are found between the decadal evolution of seasonal temperatures over the full domain and the three sub-regions (Fig. 10). The period prior to AD 1200 reveals relatively stable temperature levels except for the CCSM4 simulation, which shows higher temperature during the twelfth century. The ECHO-G-MM5 simulation, which it should be noted that is not forced by changes in volcanic activity (see also Section 4.3.1), shows in both seasons a slightly positive temperature trend that lasts until the twelfth century and is subsequently followed by a long-term decline in temperature (Fig. 10). This long-term cooling is most likely induced by changes in external forcing and thus related to long-term changes in the solar activity. For the CCSM4 and MPI-ESM-P realisations, there are common signals induced by large volcanic eruptions in the thirteenth century (e.g., the great Samalas volcanic eruption in AD 1257, Lavigne et al., 2013, Sigl et al., 2015 and the Quilotoa eruption in AD 1275, Mothes and Hall, 2008, Ledru et al., 2013, Sigl et al., 2015) that led to negative April-September temperature anomalies. Despite their strength, the eruptions are not reflected in the second and third ensemble of the MPI-ESM-P simulations (Fig. 13 upper panel), which might partly be related to the slight differences in the experiment setup (Jungclaus et al., 2014). In addition, temperature response to volcanic eruptions depends as well on inadequate aerosol particles representation and uncertainties in eruption location and time of year (Timmreck et al., 2009, Toohey et al., 2011, Anchukaitis et al., 2012, Stoffel et al., 2015). Disruption in ray exchange due to volcanic activity is found to be overestimated in different climate models (Brohan et al., 2012, Meehl et al., 2012, Landrum et al., 2013, Berdahl and Robock, 2013, Marotzke and Forster, 2015, Stoffel et al., 2015) due to model difficulty in capturing dynamic responses in the stratosphere (Shindell et al., 2003) and potential errors in ice core interpretation when generating volcanic reconstructions (Schneider et al., 2009, Sigl et al., 2015). Following the above, the temperature decline in the aftermath of largest tropical eruptions like the great Samalas (Sigl et al., 2015) do not scale linearly with the amount of sulphate aerosols they eject ( cf. also discussion in Timmreck et al., 2009, Crowley and Unterman, 2013, Stoffel et al., 2015). However, the volcanic outbreaks are also 
visible for the entire eastern Mediterranean region, as shown by the spatial average of the annual mean surface temperature (Fig. 16) and are in agreement with the new proxy-based spatial reconstruction of the European - Mediterranean summer temperature fields back to $755 \mathrm{BCE}$ (Euro_Med Consortium, 2015).
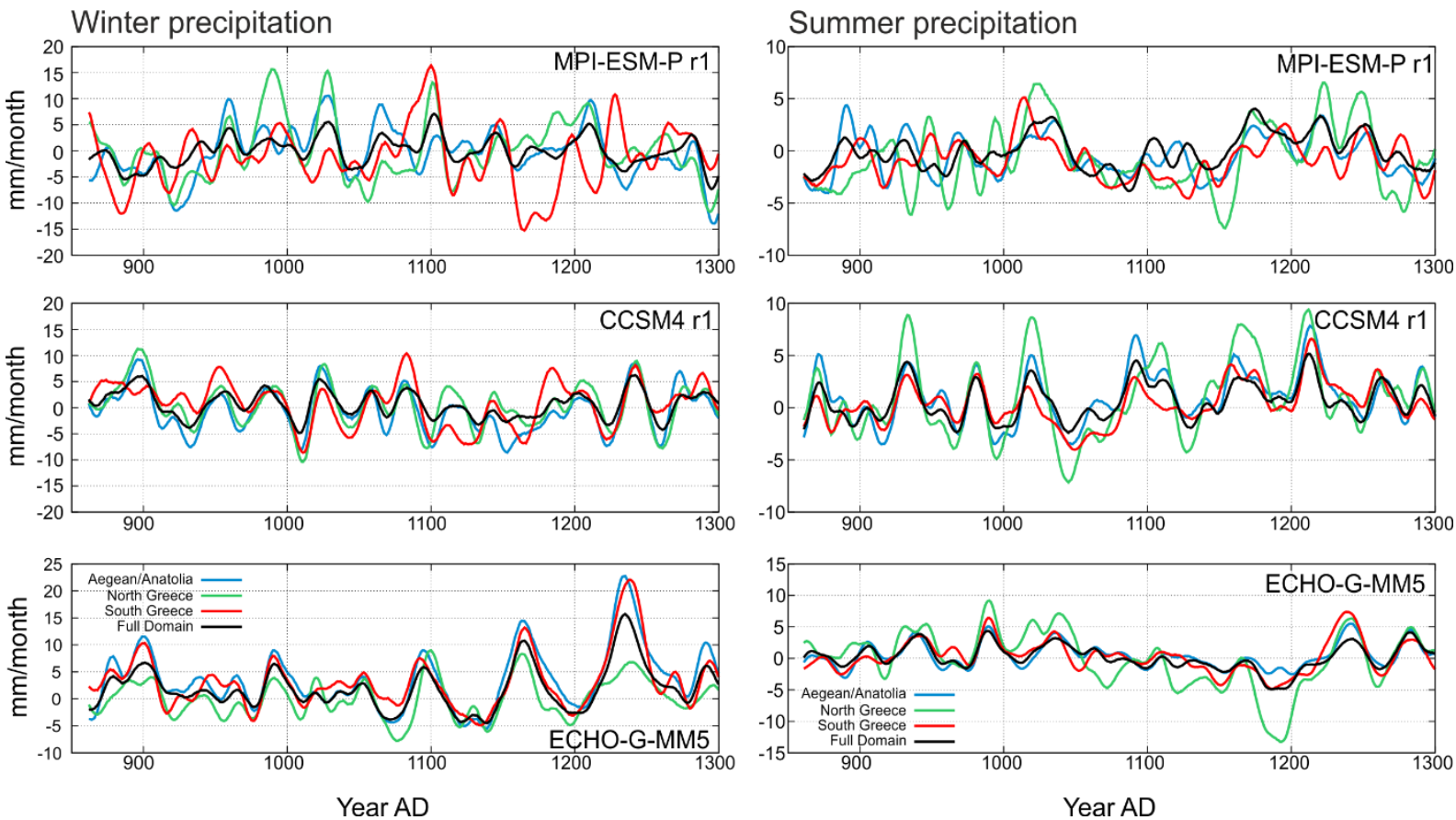

Fig. 11. As Fig. 10 but for extended winter (October - March) and extended summer (April - September) precipitation anomalies (in $\mathrm{mm} / \mathrm{month}$ ).

\subsubsection{A long-term trend towards wetter conditions in ca. AD 850-1000 in western Anatolia} For the Aegean/Anatolia sub-region (Fig. 1), only the MPI-ESM-P r1 simulation indicates elevated levels of precipitation during the extended winter for the period AD 850-1000 (Fig. 11). The CCSM4 simulation shows constant precipitation levels in this period for both seasons. For the thirteenth century, the ECHO-G-MM5 simulation shows an increase in October-March seasonal precipitation. Interestingly, in this regional simulation the sub-regions vary quite coherently in contrast to the GCMs. During summer, however, larger and more accentuated differences between northern Greece and the other sub-regions occur for the first two centuries of the study period, most likely because of the relatively higher mean rainfall during the warm season of the year (see also Fig. 7). It should be 
noted that higher precipitation totals are also connected with higher variability, especially over regions characterised by complex terrain, such as Northern Greece (Fig. 7).

\subsubsection{Stable and relatively warm-wet conditions in northern Greece AD 1000-1100}

The beginning of the eleventh century is characterised by strong temporal precipitation variations for Northern Greece in the MPI-ESM-P r1 simulation and throughout the year (Fig. 11). The CCSM4 r1 simulation also shows increased rainfall during the extended summer, whereas no clear-cut signal is discernible during the cold and wet part of the year (Fig. 11). Interestingly, at the beginning of the eleventh century, the two GCMs show a different behaviour of the soil moisture conditions (Fig. 12). During summer, lower values are simulated in the CCSM4 r1, whereas the MPI-ESM-P simulation shows the opposite situation with increased levels in soil moisture. The ECHO-G-MM5 simulation shows rather stable soil moisture conditions, especially during the cold season. Due to the persistence of soil moisture conditions compared to precipitation, similar characteristics are also found for the respective winter half of the year in the different simulations for the full domain and the sub-regions (Fig. 11).
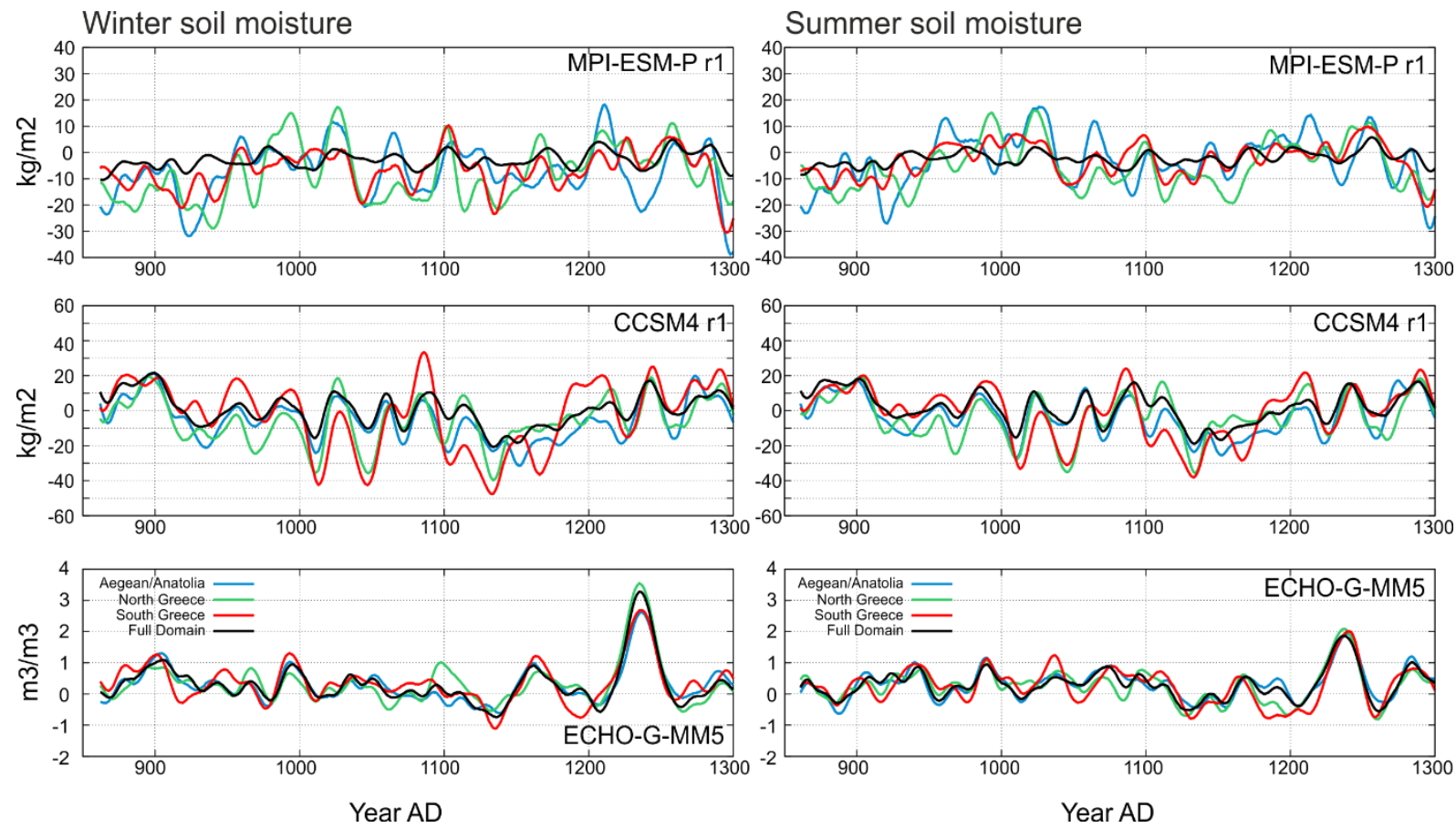

Fig. 12: As Fig. 10 but for extended winter (October - March) and extended summer (April - September) soil moisture anomalies (in $\mathrm{kg} / \mathrm{m} 2$ and $\mathrm{m} 3 / \mathrm{m} 3$ for the GCMs and ECHO-G-MM5, respectively). 


\subsubsection{Interannual variability over the Byzantine lands}

A suitable tool for addressing changes in the interannual variability, and in particular changes in the amplitude of temperature change in different periods, is the estimation of the standard deviation of climatic indices using shifting windows, the so-called running standard deviation. This approach is applied only to the simulated temperature for the full domain, because of the high degree of coherence among the different regions as can be seen in Figs. 10-12. The running standard deviations for the temperatures of the MPI-ESM-P and CCSM4 simulations are presented in the lower part of

Fig. 13. One general outstanding feature relates to the changes in the mid-thirteenth century connected with the strong volcanic activity of the period (Fig. 16). Due to the lower impact of this volcanic event on the MPI-ESM-P r2 and r3 simulations (see temperature evolution of $r 2$ and $r 3$ displayed in Fig. 13, Jungclaus et al., 2014), the standard deviation change is moderate compared to the other simulations. For the earlier periods, all simulations show quite stable conditions and no general pattern can be identified in changes in the interannual variability over all simulations.
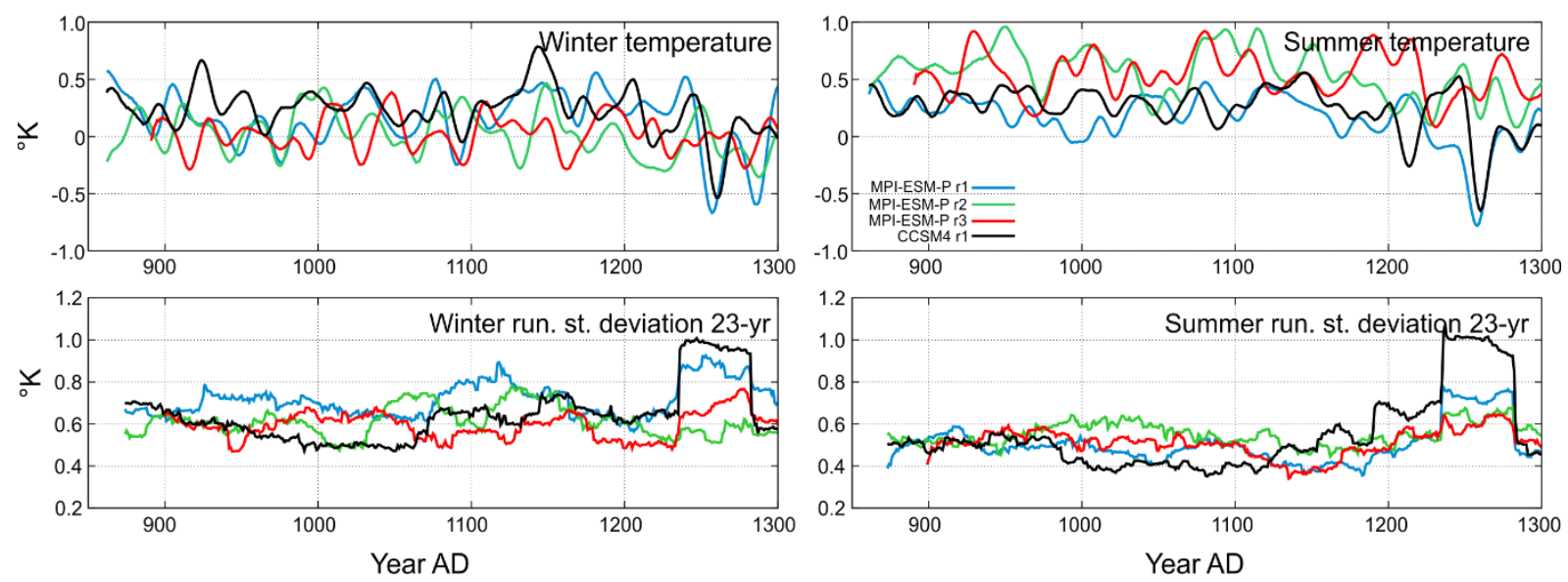

Fig. 13: Extended winter and extended summer temperature anomalies with respect to the AD 1500-1850 reference period (upper panel) and temperature running standard deviations (23-yr, lower panel) over the medieval Byzantine lands for the MPI-ESM-P and the CCSM4 simulations.

\subsubsection{Periods of political or economic instability}

Periods of political or economic instability in the Byzantine empire are investigated here in greater detail. These periods are i) AD 920-930, the period of a great famine, reflected in documented remissions of taxation and increasing structural changes in the rural society - in particular increased 
peasant dependency on middling and larger-scale estate-owners, with a consequent alienation of fiscal resources from the central government to the advantage of élite landlords (Kaplan, 1992, pp. 461-462; Morris 1976), ii) AD 1025-1100, years characterised by frequent controversies over the imperial throne, and the loss of Anatolia to the Turks by the end of that century (Cheynet, 1998, Angold, 2008), and iii) AD 1175-1200, a period of political crisis that weakened the empire in the years leading up to the Fourth Crusade and the fall of Constantinople in AD 1204 (Magdalino, 2008).

The outputs of the climate simulations for these periods were used, including also the years that preceded the respective periods. In a first step, the mean differences are calculated between the selected periods and the AD 1500-1850 seasonal mean (Fig. 14). Due to the higher spatial variability of precipitation (Figs. 6 and 7) the sub-region Aegean/Anatolia is presented, whereas for temperature the full domain is shown.
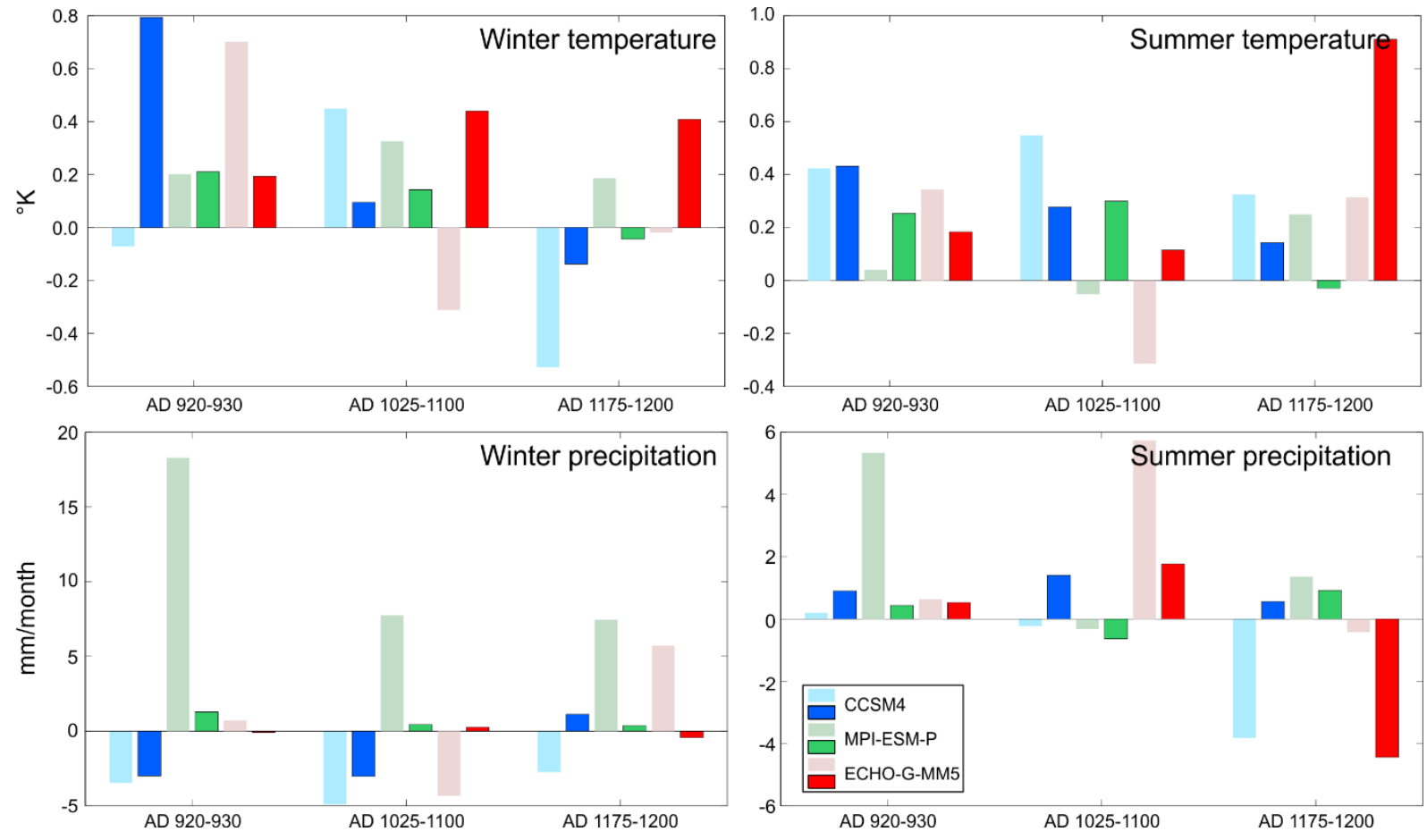

Fig. 14: Temperature and precipitation differences with respect to the 1500-1850 reference period for the three politically / economically instable periods (AD 920-930, AD 1025-1100 and AD 1175-1200) in Byzantium. Temperature differences correspond to the full domain and precipitation differences to the Aegean/Anatolia sub-region. Lighter colours represent the preceding five years to the respective periods. 
For AD 920-930 and AD 1025-1100 temperatures show warmer conditions compared to AD 15001850, although the amplitude varies among the simulations. Warmer temperatures during the extended winter season also characterise most of the preceding five-year periods. Higher temperatures characterise all periods during the extended summer season and the preceding fiveyear periods, which agree with the spatial proxy reconstruction by Euro_Med Consortium (2015). It should be noted that the reference period AD 1500-1850 that coincides with the Little Ice Age (AD 1450-1850, Masson-Delmotte et al., 2013), is a cooler period compared to the twentieth century (Fig. 5.8f and Fig. 5.9g-i for the second part of the twentieth century in Masson-Delmotte et al., 2013).

With respect to precipitation conditions, changes are small and heterogeneous in the different periods and between the models. Due to the complexity of the hydrological cycle, climate models cannot simulate correctly changes during decades in the regional scale, in addition to moderate changes in external forcing (compared to changes between glacial and interglacial periods). Moreover, also other subtropical and Mediterranean climate regions in the world (south-western North America) show no clear-cut relationships between changes in the hydrological cycle and changes in external forcing during the last millennium pointing to the high amount internally dominated variability within the hydrological cycle (cf. Coats et al., 2015).

In order to investigate the spatial co-variability within the different periods, the same analyses were carried out for the spatially resolved fields. As an example, the MPI-ESM-P r1 simulation is presented here (Fig. 15). The slightly increased temperature levels of the Byzantine periods compared to the pre-industrial reference period AD 1500-1850 (Fig. 14) is also reflected in the temperature fields (Fig. 15). The dependence of the amplitude of the temperature anomaly on the land-sea distribution mainly towards the Mediterranean Sea is evident in some of the patterns. For instance, during the extended summers of the years AD 920-930, stronger temperature anomalies characterise the land 
areas as compared to the moderate anomalies over the Aegean and Black Seas (compare also with Fig. 7).

The precipitation patterns are more heterogeneous (Fig. 15) as the processes involved in the generation of rainfall are more complex and spatially more variable compared to temperature, especially over complex terrain (see also Section 4.1). This is visible for example for the summers AD $1175-1200$ that are found to be wetter than the mean conditions of the period AD 1500-1850 (positive precipitation anomaly) over the Aegean and eastern Greece, whereas the southern rim of the domain indicates similar or drier conditions as for the reference period. During the extended winter season, which is characterised by slightly higher mean precipitation (see also Fig. 6), the regional differences in precipitation are in cases even larger (Fig. 15). From a hydrological point of view the different periods show no clear-cut synchronous pattern of increased or decreased precipitation over the eastern Mediterranean. In contrast, temperatures during the periods of interest show in general warmer conditions compared to the reference period, representing in large parts the period of the Little Ice Age (Fig. 15). 
Winter temperature

(a)
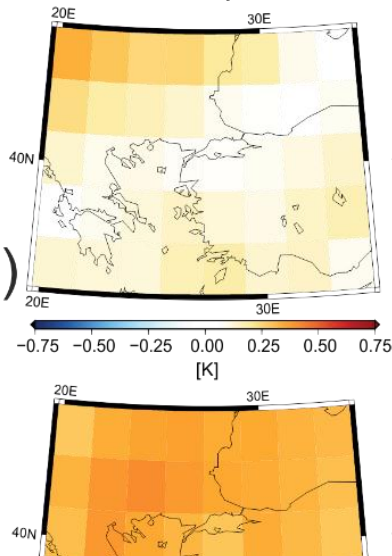

(b)
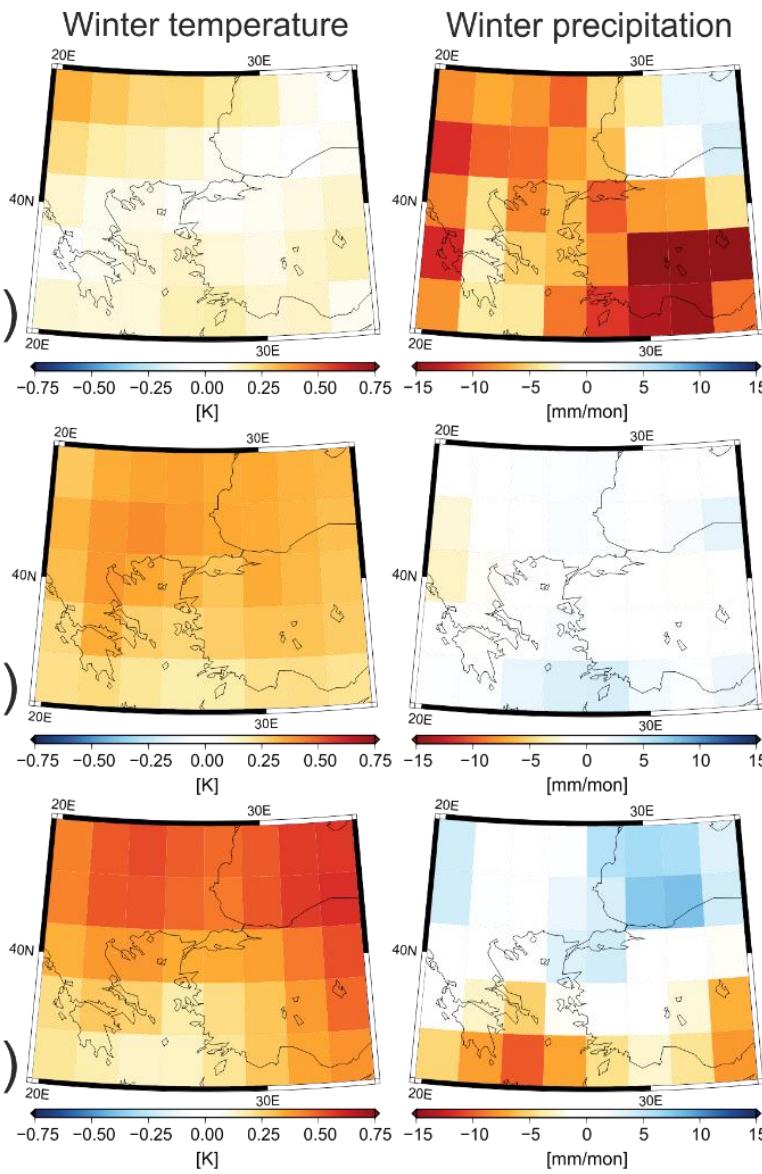

Summer temperature
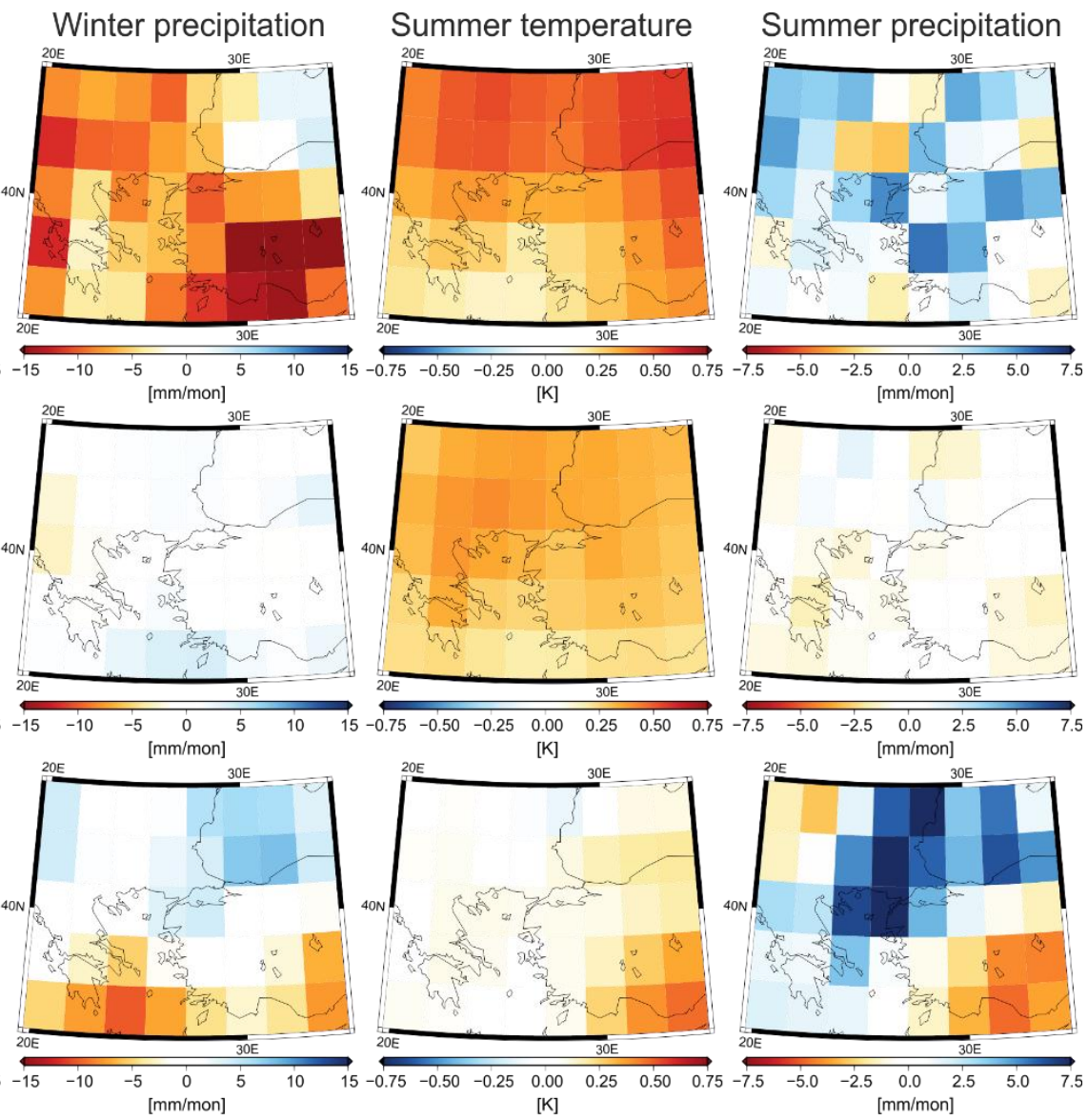

Fig. 15: MPI-ESM-P r1 simulation spatially resolved differences of seasonal temperature $\left({ }^{\circ} \mathrm{C}\right)$ and precipitation (mm/month) with respect to the AD 1500-1850 reference period for the periods (a) AD 920-930, (b) AD 1025-1100 and (c) AD 1175-1200 in Byzantium.

Although the periods selected in the models do not reflect the real climate evolution - and due to the absence of changes in the external forcings a common signal would be a coincidence - the model simulations show a considerable amount of spatial variability, especially for the hydrological changes.

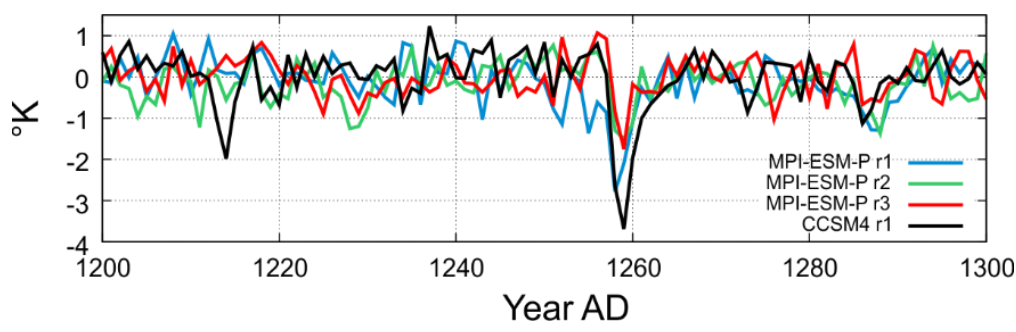

Fig. 16: Annual 2-m temperature interannual evolution for the CCSM4 and MPI-ESM-P simulations over the medieval Byzantine lands. Annual temperature anomalies are calculated with respect to the AD 1000-1850 reference period. 


\section{Discussion: climatic changes and societal change in Byzantium (ca. AD 850-1300)}

Any analysis of socio-economic and political change and transformation for any period of history requires a holistic approach that includes environmental factors, documentary evidence, and the broader geo-political context. In the case of the medieval Byzantine state, it should be clear at the outset that a short study such as this can only collate the key materials and suggest ways forward. We have quite deliberately, therefore, excluded clearly significant factors such as changing environmental situations among the neighbours of the empire, in particular the steppe peoples such as the Pechenegs and Turks, but also in Italy, a major trading partner of the Byzantine empire throughout the period AD 850-1300. Climatic shifts in the empire's commercial partners could impact on market demand as well as production, and thus on socio-economic relations within the empire itself (as, for example, in determining estate owners' choices to invest in sericulture, oleoculture or viticulture, major sources of market-derived income). Until the twelfth century Italian cities were major importers of Byzantine grain, for example, so shifts at either end of this relationship could impact negatively as well as positively at the other end. These issues are central to future, more detailed research into the causal associations between climate, environment and society in the Byzantine world, and that what we present here is intended to illustrate both the possibilities as well as the methodologies that can be employed.

The middle Byzantine period (ca. AD 800-ca. AD 1200) generated a considerable body of evidence for the study of climate and society. Natural proxy archives and textual records on past climate, as well as historical, palaeoenvironmental and archaeological data together generate a substantial body of information on specific climate events, variations in weather and climate, societal changes, as well as economic and political fluctuations (Sections 2-4). In particular, the evidence that concerns societal processes is largely multi-factorial in character, while reactions to climate and its variability in respect of both human activities as well as the reactions to climate variability on the part of different sectors 
of society, both as reported by contemporaries as well as revealed by, for example, archaeological data, have a different spatial and temporal resolution (local, daily to annual) compared with the palaeoclimate records (local to regional, seasonal to multidecadal). Moreover, most of the data relevant to Byzantine society do not build continuous time series. These different types of data, however, can now be complemented by palaeoclimate models, which determine climate system changes through given boundary conditions and changes caused through forcings. Such models help thus to identify the underlying mechanisms of observed climatic variations, and - to the extent that signal and noise can be distinguished - make it possible to separate the externally-forced climate signal from internal variability.

In the following sections, those periods and areas that have proved to be most interesting in terms of potential linkages between climatic changes and socio-economic processes are discussed in chronological order.

\section{AD 850-1050, Anatolia}

In the ninth century, the expansion of agriculture (Fig. 5) and the increase in monetary circulation

(Fig. 2) signalled the economic recovery of Byzantine Anatolia, which culminated during the eleventh century. As indicated by the three archives of Nar Gölü (Cappadocia), Sofular (Paphlagonia) and Uzuntarla (Thrace) Caves (Figs. 1 and 9) and also the lower temporally resolved record of Tecer Lake (Cappadocia), a marked shift from drier to wetter conditions seems to have occurred at the beginning of this period. This is in agreement with the CMIP5/PMIP3 models that denote wetter conditions for the Aegean/Anatolia at the same time (Fig. 11). The widespread abundance of rainfall must have resulted in more favourable conditions for agriculture in Anatolia in the ninth and tenth century. However, given the close relationship between political stability in Anatolia and agricultural expansion (Figs. 2, 5) (Izdebski et al., 2015), the climatic conditions cannot be considered as the sole causal factor in respect of economic prosperity, even if they certainly contributed substantially to 
these processes. It seems far more likely that such a change in the region during the eleventh century should be attributed to human factors rather than fluctuations in climate.

\section{AD 900-1200, southern Greece}

Later than in Anatolia and at a slower pace, southern Greece (see also Fig. 1) experienced an expansion of agriculture (Fig. 5), reaching a climax after ca. AD 1150, followed by continuing settlement growth beyond the twelfth century (Fig. 3). The beginning of this period coincides with the economic recovery after the early medieval crisis and the later eighth century, which is particularly apparent in the increase in monetary circulation from the middle of the ninth century (Fig. 2). It should be noted that the later recovery in southern Greece, in comparison with that in Anatolia (Fig. 5), is probably related to its re-integration into the Byzantine empire in the ninth century, following which there took place a gradual political stabilisation (Table I). The climatic conditions in southern Greece in the period ca. AD 900-1100 can be characterised as relatively wet, as indicated by the stable high effective humidity levels at Uzuntarla Cave and other independent palaeoclimate evidence (Fig. 9). Climate simulations (Fig. 11), as shown, are partly in agreement with this palaeoclimatic picture.

The decade from around AD 920-930 represents an unusual period in terms of socio-economic instability and the available documentary record of severe famines (Kaplan, 1992, pp. 461-462) is quite clear, and these shifts had significant implications for the state's fiscal system, for military recruitment and for the relationship between the government and the power élite at Constantinople and the increasingly independent provincial élites (Morris 1976; Frankopan 2009; Haldon 2009). This period was characterised by stronger snow accumulation as reconstructed from the Kocain Cave record (Fig. 9), and an increased frequency of cold winters in the Byzantine lands that show winter temperature conditions very close to the levels of the Little Ice Age (Fig. 15). Such conditions could be linked to the short-term subsistence crises reported by the historical sources for the AD 920s. 
From the economic point of view, the twelfth century seems to have been the most prosperous period for southern Greece, with high agricultural productivity, significant monetary exchange, and demographic expansion. This is the period during which the Byzantine empire, having made a significant recovery after the problems that had arisen in the second half of the eleventh century, was relatively strong in terms of political/military power (Table I). But it is also a period characterised by generally drier conditions (Uzuntarla Cave, Sofular Cave, Nar Gölü, Fig. 9) and high SSTs (M2, Gogou et al., this volume), as well as strong May-June precipitation variability, and a clear downward rainfall trend, as can be seen by the Aegean oak tree-rings reconstruction (Fig. 9). A tendency towards extended winter dryness is also shown by the CMIP5 models (Fig. 11), especially for the period AD 1175-1200 (Fig. 15). Byzantine society in southern Greece during the twelfth century seems, in consequence, to be relatively resilient in a context of less favourable climatic conditions.

\section{AD 900-1100, northern Greece and the Balkans}

In the tenth century, monetary circulation (Fig. 2) and cereal cultivation gradually expanded in both Bulgaria and northern Greece (Figs. 5). The relatively stable and also high SSTs from M2 together with the high humidity levels of the Uzuntarla Cave (Fig. 9) suggest that higher temperatures and more abundant precipitation facilitated the northward expansion of the Byzantine agriculturaleconomic pattern. However, the end of the eleventh century is marked by a drop in temperature and precipitation, as indicated by the north Aegean marine core M2, and Uzuntarla Cave (Thrace). Around AD 1100, a significant decrease in monetary circulation in Bulgaria (Fig. 2) seems decoupled from agricultural development, which continued without interruption (Fig. 5). The reasons for this are probably to be located in the differential impact of Pecheneg incursions from central Asia at this period, which may well have disrupted markets and monetised exchange activity without impacting in an obvious way on peasant production. The pollen data reflect a wider regional development, in contrast to the indicators for monetary exchange, which in this instance seem to reflect developments north of the Haemus range, thus areas most exposed to economic disruption (Frankopan, 1997; Stephenson, 1999). The models indicate a general reduction of rainfall in northern 
Greece and a drop towards the end of the eleventh century to the levels of the Little Ice Age in two of the simulations (Fig. 11), while the warm season is characterised by a tendency towards drier conditions. It should be noted that the twelfth century is characterised by generally dry conditions and this is evident in the palaeoclimate records of Nar Gölü, Uzuntarla Cave and Sofular Cave (Fig. 9).

\section{AD 1100-1200, Anatolia}

Following the Turkish conquest and occupation of the Anatolian plateau (Table I) and for almost the entire twelfth century, palaeoclimate records (Nar Gölü, Uzuntarla Cave and Sofular Cave) in the eastern Mediterranean point to drier conditions almost everywhere across the Byzantine empire (Fig. 9). An important decline in agricultural production seems to have occurred in Anatolia already prior to AD 1100. The invasion of the Seljuks and the migration of the Turkoman nomads into central Anatolia after AD 1071 appear to have caused a serious retrenchment in the established economic system, while at the same time as these events were taking place, the region also had to cope with lower rainfall. Interestingly, whereas there is a clear decline in cereal cultivation over much of Anatolia (Fig. 5), the annually-resolved Nar Gölü pollen data show only small-scale and short-term fluctuations in cereal and pasturing-related pollen (England et al., 2008). This could suggest that the impact of both climate as well as human activity (such as raiding warfare, for example) depended on local environmental conditions, agricultural practices (cf. Crumley, 1994) and the nature of local social organization. Finally, the Seljuk expansion into the Middle East may have been encouraged by particularly cool climatic conditions over central Asia in the early eleventh century. Bulliet (2009) showed that cooling had a more dramatic impact on nomadic Seljuk society than on neighbouring sedentary cultures, since Seljuk camels were temperature-sensitive, and cooling forced a migration from the northern to the southern fringes of the Karakum desert. But there has as yet been no clear demonstration that climate was instrumental in the Seljuk invasion of Anatolia (cf. Ellenblum, 2012, and its reviews by Frankopan, 2013, and Burke, 2013) and more research is required in this direction. 
These unstable and rather dry conditions, especially during the second half of the twelfth century prevailed also in Greece and Macedonia, where economic growth continued throughout the whole century (Figs. 2-5). The contrast between the Anatolian and Greek parts of the Byzantine socioeconomic system suggests that it was generally resilient to medium-scale climate fluctuations, as well as to increased interannual variability, except where there also occurred significant political problems. In other words, since Byzantine Greece and Macedonia did not directly suffer from the Seljuk invasion of Anatolia, the agrarian economies of these regions of the Byzantine Empire coped quite well with the climatic stress of the twelfth century.

AD 1175/1180-1200, Byzantine lands

The period of AD 1175/1180-1200, preceding the fall of Constantinople in AD 1204 and the partial collapse of the Byzantine state, was one during which the empire experienced considerable internal instability (Magdalino, 2008). In addition, a major rebellion in the central Balkans led to the creation of the so-called Second Bulgarian empire (Ritter, 2013). The question arises as to whether there was indeed a climatic dimension to these historical developments that could have limited the resources available to the Byzantine imperial government and increased social tensions.

In fact, the empire did experience "unusual" climatic conditions during precisely these years. Dry conditions are indicated by all palaeoproxy records, on both sides of the Aegean Sea (Fig. 9 and Cook et al., 2015a). Palaeomodels and the Euro_Med Consortium (2015) summer temperature reconstruction also show clearly the prevalence of colder summers across virtually all three decades that preceded the fall of Constantinople in AD 1204 (Table I). More specifically, the tree-ring based May-June rainfall reconstructions and information from the Uzuntarla and Sofular Caves (Fig. 9) point to drier conditions over the greater North Aegean area. Additionally, data from Kocain Cave show a higher frequency of cold and likely drier winters. Finally, Nar Gölü (Fig. 9) indicates rainier summers for the last decades of the twelfth century. 
Fig. 17 presents the average proportion of olive pollen for the highlands of Macedonia. A period of growth in the values of olive pollen in this part of Macedonia occurred during the ninth and tenth century. Given that wind can transport olive pollen over longer distances (Bottema and Woldring, 1990), this trend must reflect a general increase in the presence of olive trees (hence, expanding olive cultivation) over a larger area in the north of Greece. This growing trend is no longer visible in the eleventh century, and towards the end of the twelfth century the average olive pollen values started to decline rapidly. These changes in the regional olive pollen record from the northern Aegean show interesting correlations with two climate proxies. First, the northern Aegean SSTs reconstruction shows a declining trend after $A D 1000$ (Fig. 9), potentially indicating that temperatures were becoming cooler over this part of Greece, which would limit the natural potential for olive cultivation in this area. Moreover, the dendro-based reconstructions of May-June precipitation for the northern Aegean also show a declining trend, this time dated to the twelfth century (Fig. 9). As the late spring rains are crucial for olive harvests, this factor might have additionally worked against olive cultivation in Macedonia and northern Greece in general. In addition, since - as already indicated - the AD 1180s and AD 1190s were a period of relative political instability, with warfare in the Balkans and internal political tensions and conflict in and around the capital at Constantinople that affected the trade and market for olive oil. In contrast, there appears to be no indication of longer-term decline in cereals (Fig. 5), although of course this does not exclude some short-term fluctuations in grain harvests, fluctuations that would not, of course, be reflected in the pollen data. Whereas it is quite probable that the harvests in the years AD 1180-1200 were in general lower as a result of adverse climatic conditions, there is more certainty with respect to the poor olive harvests thanks to the observed longer-term decrease in olive pollen in Macedonia. All these factors likely amplified any instability within the Byzantine socio-political system during the last part of the twelfth century, even though positive demographic trends generally remained unaffected (Figs. 4 and 5). Interestingly, the relatively stable May-June precipitation patterns after AD 1230 (Fig. 
9) do not seem to have helped to reverse the overall declining trend in olive cultivation in northern Greece (Fig. 17).

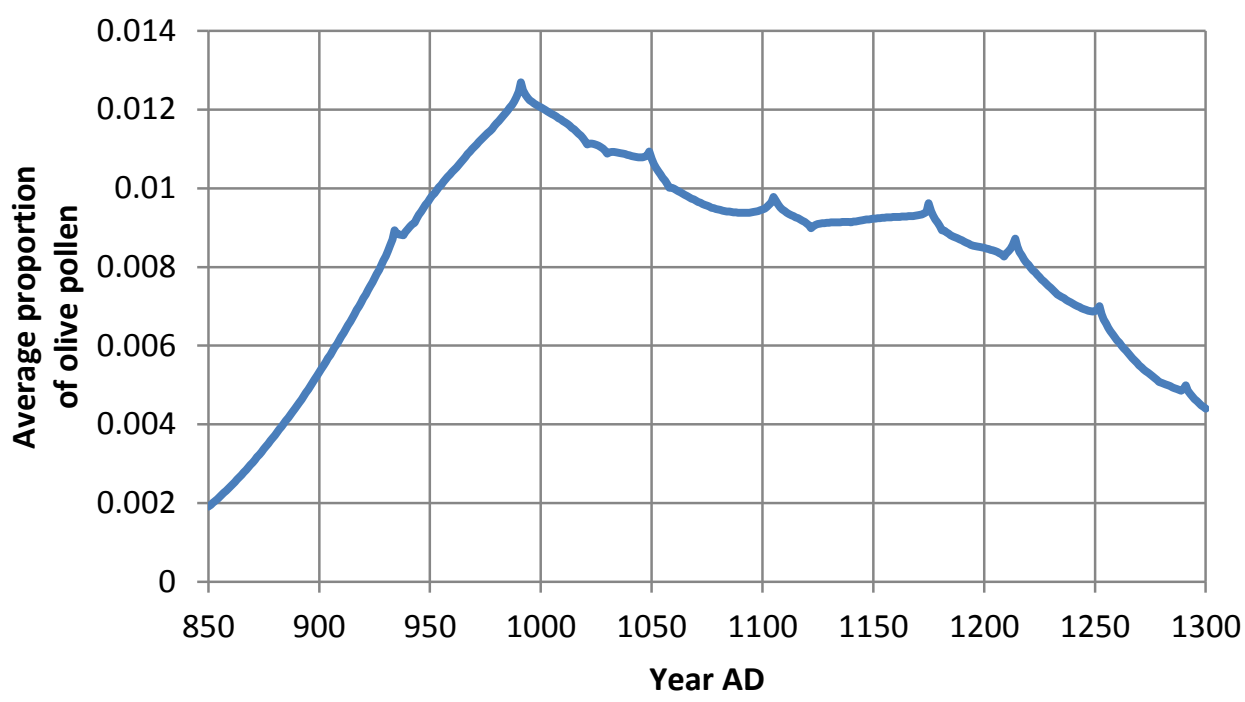

Fig. 17: Average proportion of olive pollen in the highlands of Macedonia (adapted from Izdebski et al., 2015).

AD 1200-1300, Anatolia

All three model simulations show a significant reduction in winter temperatures around the middle of the thirteenth century related to the great Samalas volcanic eruption (Fig. 16, Sigl et al., 2015, Stoffel et al., 2015) and other tropical volcanic eruptions of that period. Severe winters can damage both vineyards and olive cultivation, since as noted already both of these plants are sensitive to prolonged frost and very low temperatures during winter. Unfortunately, there are no data on olive or vine cultivation or the trade in wine or olive oil during the thirteenth century to help trace the immediate impact of these severe winters on the regional economy. However, it is interesting to observe that the period of severe winters temporally coincides with the final collapse of Byzantine political control over the valleys of western Anatolia (Thonemann, 2011, pp. 270-278; cf. Fei et al., 2007 , for another case of the impact of a volcanic eruption on medieval political history). At that time, these valleys were inhabited by settled agriculturalists whose identity was mostly Byzantine, and nomad pastoralists, who were predominantly Turkoman. In the course of the second half of the thirteenth century, the Byzantine authorities from Nicaea and then Constantinople gradually lost 
military and political control over these complex local communities, as they were absorbed into the Turkoman beyliks of western Anatolia (Laiou, 1972, pp. 21-30). Possibly that section of the population whose economic activities were centred on cereal, vine, vegetable and olive cultivation, was weakened by the severe winters, conditions that may have been less damaging for the Turkoman pastoralists. The economic impact of such severe winters would consequently reduce the tax resources available to the local Byzantine authorities, while the imperial government from Nicaea was too busy with the recovery of the control of Constantinople to deal with local problems in western Anatolia (Table I).

For the sixty years after the fall of Constantinople (Table I), eastern Bulgaria shows a positive trend in monetary exchange (Fig. 2) and forms in the thirteenth century the core of the new, flourishing Bulgarian empire (Ducellier, 2008). The contraction of monetary circulation is thus observable on sites associated with the Byzantine economic system that started to break down after the fall of Constantinople in AD 1204, and consequent upon the political and economic fragmentation that followed (Laiou and Morrisson, 2007).

\section{Climate models}

Although the increased spatial resolution of the climate models used in this review, a detailed view of the evolution of the climate in the eastern Mediterranean cannot yet be achieved. Smaller-scale factors, such as complex coastlines and orography and short timescale sea-land interactions, as well as major processes, such as the connection between the Mediterranean Sea and the North Atlantic, still cannot be realistically represented.

The CMIP5/PMIP3 simulations revealed a high degree of internally generated variability. None of the formulated hypotheses can be falsified concerning i) exact timing and ii) the extent and spatial representation of the model-based results in comparison with the empirical evidence, i.e., natural proxy archives and historical or archaeological evidence. This does not disqualify the ability of both 
approaches to take into account some general considerations. Inferences about the true climatic evolution can only be derived from the empirical evidence. Climate models may only represent several possible evolutions of climate under certain configurations in the external background. For instance, the CMIP5/PMIP3 model simulations are carried out with the same protocol using changes in Earth's orbital parameters, solar output and volcanic activity but they all show different evolution on the decadal-to-multi decadal time scale.

\section{Conclusions}

This analysis of the complex interactions between medieval climate, environment and human activity in Byzantium combined paleaeoclimate records and simulations with textual and archaeological evidences. However, establishing firm links between climate change and human activity remains challenging due to the complexity and heterogeneity of available climatic and societal data.

The comparative use of palaeomodels in combination with palaeoclimate information and societal evidence significantly contributes to a better understanding of both the drivers behind the climate system as well as those behind the coupled climate-society system. In this way, we can clarify the links between climate variability and societal impacts and thus study the human capabilities in adjusting to a changing environment.

Changes in solar and volcanic activity probably influence climate on annual to decadal time scales. However, during the middle Byzantine period, no prolonged changes in either solar or volcanic activity are evident. It seems most likely, therefore, that changes seen in the model simulations are induced by the internal variability generated by the interactive coupling between the different climatic components.

For Byzantium, the ninth and tenth centuries were marked by an agricultural and demographic expansion that was favoured by abundant rainfall and a mild climate. During the following century, 
while such favourable conditions continued, parts of the empire also experienced external political pressures, such as the movement of Turkoman groups under Seljuk hegemony into Anatolia, which coincided with the end of the agricultural expansion in that region.

The twelfth century saw the climax of the medieval Byzantine empire, with substantial agricultural productivity, intensive monetary exchange, demographic growth, and its pre-eminent international political situation. This period also saw a shift towards warmer temperatures, high precipitation variability and drier winter conditions. However, these adverse climatic conditions did not affect the Byzantine socio-economic system, which reached its maximum development at precisely this point. Across this period, at least, Byzantine society was resilient in the face of the impacts of climate variability. In contrast, towards the end of the same century (around AD 1175-1200), a period of unusual climatic conditions set in, with heightened winter aridity and summer cooling, coinciding with the years of internal political and economic disruption that preceded the Latin occupation of Constantinople (AD 1204). The possibility, indeed probability, that such shifts in climatic conditions contributed to the instability of the Byzantine socio-political system at this time cannot be excluded, shifts that may have induced heightened factional competition over resources as well as other forms of conflict, all of which facilitated the success of the Fourth Crusade.

In the middle of the thirteenth century, cooler and more arid conditions are visible in the lake palaeoclimate records and the models capture well a significant decline in temperature connected with the volcanic eruption of Samalas around AD 1257. The potential impact of such short-term climatic variation may have been strong for an agrarian society such as the Byzantine, the resourcebase of which might have been weakened through the strong cooling. Interestingly, the event coincides well with the final collapse of Byzantine political control over western Anatolia.

To conclude, we would suggest that climate was a significant contributory factor in the socioeconomic changes that took place in Byzantium during the MCA, but that it was not the sole factor. 
Rather, the impact of climate change amplified or exacerbated a range of inter-related pressures that placed stress on various key elements of Byzantine society and economy. These included external forces such as the social dislocation and economic disruption generated by the Turkic raids and subsequent occupation of much of Anatolia from the AD 1050s on; the Pecheneg raids and dislocation in the Balkans from the AD 1070s; and the conflicts with Venice and other western powers that led up to the fall of Constantinople to the Latins in AD 1204. But they also included preexisting and systemic internal socio-economic tensions between the state, various factional elements of the ruling élite, and the tax-paying rural populations of the provinces. The inter-relationship between these varying factors reinforces the conclusion that a comprehensive answer to the question of Byzantine social, economic and cultural resilience in the face of both climate change as well as other systemic or conjunctural pressures requires more detailed research into the underlying mechanisms and the exact nature of the causal relationships between human and natural environmental factors.

\section{Acknowledgments}

This paper emerges as a result of a workshop at Costa Navarino and the Navarino Environmental Observatory (NEO), Greece in April 2014, addressing Mediterranean Holocene climate and human societies. The workshop was co-sponsored by IGBP-PAGES, NEO, the MISTRALS/ PaleoMex program, the Labex OT-Med, the Bolin Centre for Climate Research at Stockholm University, and the Institute of Oceanography at the Hellenic Centre for Marine Research. Adam Izdebski also acknowledges the research funding received from the National Science Centre (NCN) (DEC-2012/04/S/HS3/00226), Poland, through the centre's postdoctoral fellowships scheme. J. Luterbacher also acknowledges support from the DFG Project Historical Climatology of the Middle East based on Arabic sources back to $A D 800$. 


\section{References}

Anchukaitis, K.J., Breitenmoser, P., Briffa, K.R., Buchwal, A., Büntgen, U., Cook, E.R., D'Arrigo, R.D., Esper, J., Evans, M.N., Frank, D., Grudd, H., Gunnarson, B.E., Hughes, M.K., Kirdyanov, A.V., Körner, C., Krusic, P.J., Luckman, B., Melvin. T.M., Salzer, M.W., Shashkin, A.V., Timmreck, C., Vaganov, E.A., Wilson, R.J.S., 2012. Tree rings and volcanic cooling, Nature Geoscience 5, 836837. http://dx.doi.org/10.1038/ngeo1645

Anderson, W., 2008. Settlement change in Byzantine Galatia: an assessment of finds from the general survey of central Anatolia. Anatolian Archaeological Studies 17, 233-239.

Angold, M., 2008. Belle epoque or crisis? (1025-1118). In: Shepard, J. (Ed.), The Cambridge History of the Byzantine Empire C. 500--1492. Cambridge University Press, Cambridge, pp. 583-626.

Armstrong, P., 2002. The Survey Area in the Byzantine and Ottoman Periods. In: Cavanagh, W.G. et al. (Eds.), The Laconia Survey: Continuity and Change in a Greek Rural Landscape, Annual of the British School in Athens / Supplementary Volume. British School at Athens, London, pp. 339402.

Bakker, J., Paulissen, E., Kaniewski, D., Poblome, J., de Laet, V., Verstraeten, G., Waelkens, M., 2013. Climate, people, fire and vegetation: new insights into vegetation dynamics in the Eastern Mediterranean since the 1st century AD. Climate of the Past 9, 57-87.

Barboni, D., Harrison, S.P., Bartlein, P.J., Jalut, G., New, M., Prentice, I.C., et al., 2004. Relationships between plant traits and climate in the Mediterranean region: an analysis based on pollen data. J. Veg. Sci. 15, 635-646.

Beckh, H. (Ed.), 1895. Geoponica: sive Cassiani Bassi scholastici De re rustica eclogae, Bibliotheca scriptorum Graecorum et Romanorum Teubneriana. Teubner, Lipsiae.

Berdahl, M., Robock, A., 2013. Northern Hemispheric cryosphere response to volcanic eruptions in the Paleoclimate Modeling Intercomparison Project 3 last millennium simulations. Journal of Geophysical Research 118, 12,359-12,370. http://dx.doi.org/10.1002/2013JD019914.

Bottema, S., Woldring, H., 1990. Anthropogenic Indicators in the Pollen Record of the Eastern Mediterranean. In: Bottema, S. et al. (Eds.), Man's Role in the Shaping of the Eastern Mediterranean Landscape, Rotterdam: Balkema, pp. 231-264.

Bourbou, C., Fuller, B., Garvie-Lok, S., Richards, M., 2011. Reconstructing the diets of Greek Byzantine populations (6th-15th centuries $A D$ ) using carbon and nitrogen stable isotope ratios. American Journal of Physical Anthropology 146 (4), 569-581.

Bradley, R.S., Hughes, M.K., Diaz, H.F., 2003. Climate in Medieval Time. Science 302, 404-405. http://dx.doi.org/10.1126/science.1090372

Brázdil, R., Pfister, C., Wanner, H., von Storch, H., Luterbacher, J., 2005. Historical climatology in Europe - The State of the Art. Climatic Change 70, 363-430.

Brewer, S., Guiot, J., Barboni, D., 2007. Pollen data as climate proxies In: Elias, S. (Ed.), Encyclopedia of Quaternary Sciences, Vol. 3. Elsevier, Oxford, 2498-2510.

Brohan, P., Allan, R., Freeman, E., Wheeler, D., Wilkinson, C., Williamson, F., 2012. Constraining the temperature history of the past millennium using early instrumental observations. Climate of the Past 8, 1551-1563. http://dx.doi.org/10.5194/cp-8-1551-2012

Bulliet, R.W., 2009. Cotton, climate, and camels in early Islamic Iran : a moment in world history. Columbia University Press, New York ; Chichester.

Burke, E., 2013. Ronnie Ellenblum. The Collapse of the Eastern Mediterranean: Climate Change and the Decline of the East, 950-1072. The American Historical Review 118, 1286-1286. http://dx.doi.org/10.1093/ahr/118.4.1286

Chen, J., Chen, F., Feng, S., Huang, W., Liu, J., Zhou, A., 2015. Hydroclimatic changes in China and surroundings during the Medieval Climate Anomaly and Little Ice Age: spatial patterns and possible mechanisms. Quaternary Science Reviews 107, 98-111. 
Cheynet, J.-C., 1998. La résistance aux Turcs en Asie Mineur entre Manzikert et la Première Croisade. In: Eupsychia: mélanges offerts à Hélène Ahrweiler. Publications de la Sorbonne, Paris, pp. 131147.

Cheynet, J.-C., 2000. L'aristocratie byzantine (VIIIe-XIIle siècle). Journal des Savants, pp. 281-322.

Cheynet, J.-C., 2004a. L'expansion byzantine durant la dynastie macédonienne. In: Cheynet, J.-C. (Ed.), Le monde byzantin. Presses universitaires de France, Paris, pp. 23-42.

Cheynet, J.-C., 2004b. Byzance entre le Turcs et les Croisés. In: Cheynet, J.-C. (Ed.), Le monde byzantin. Presses universitaires de France, Paris, pp. 43-65.

Coats, S., Smerdon, J.E., Cook, B.I., Seager, R., 2015. Are simulated megadroughts in the North American Southwest forced? Journal of Climate 28, 124-142. http://dx.doi.org/10.1175/JCLI-D14-00071.1.

Cook, B.I, Anchukaitis, K.J., Touchan, R., Meko, D.M., Cook, E.R., 2015a. Mediterranean drought variability over the last millennium. J. Geophys. Res., in revision.

Cook, E.R., Seager, R., Kushnir, Y., Briffa, K.R., Büntgen, U., Frank, D., Krusic, P.J., et al. 2015b. Old World droughts and pluvials during the Common Era. Science Advances, in press.

Croke, B., 1990. Climatology and Byzantine Studies (summary). Byzantine Studies in Australia, Newsletter 24, 7.

Crowley, T.J., 2000. Causes of Climate Change Over the Past 1000 Years. Science 289, 270-277. http://dx.doi.org/10.1126/science.289.5477.270.

Crowley, T.J., Unterman, M.B., 2013. Technical details concerning development of a $1200 \mathrm{yr}$ proxy index for global volcanism. Earth Syst. Sci. Data 5, 187-197. http://dx.doi.org/10.5194/essd-5187-2013, 2013.

Crumley, C.L., 1994. The Ecology of Conquest: Contrasting Agropastoral and Agricultural Societies' Adaptations to Climatic Change. In, Crumley, C.L. (Ed.), Historical ecology : cultural knowledge and changing landscapes. School of American Research Press, Santa Fe, pp. 183-201.

Davis, J.L., Alcock, S.E., Bennet, J., Lolos, Y.G., Shelmerdine, C.W., 1997. The Pylos Regional Archaeological Project Part I: Overview and the Archaeological Survey. Hesperia: The Journal of the American School of Classical Studies at Athens 66, 391-494. http://dx.doi.org/10.2307/148395.

Diaz, H.F., Trigo, R., Hughes, M.K., Mann, M.E., Xoplaki, E., Barriopedro, D., 2011. Spatial and temporal characteristics of climate in Medieval Times Revisited. Bulletin of the American Meteorological Society. http://dx.doi.org/10.1175/BAMS-D-10-05003.1.

Ducellier, A., 2008. Balkan powers: Albania, Serbia and Bulgaria (1200-1300). In: Shepard, J. (Ed.), The Cambridge History of the Byzantine Empire C. 500--1492. Cambridge University Press, Cambridge, pp. 779-802.

Easton, C., 1928: Les hivers dans I'Europe occidentale. Leyden: E.J. Brill.

Eastwood, W.J., 2006. Palaeoecology and eastern Mediterranean landscapes: Theoretical and practical approaches. In: Haldon, J. (Ed.), General issues in the study of medieval logistics: sources, problems, and methodologies. Brill, Leiden, pp. 119-158.

Eddy, J.A., 1976. The Maunder Minimum. Science 192, 1189-1202.

Ellenblum, R., 2012. The Collapse of the Eastern Mediterranean: Climate Change and the Decline of the East, 950-1072. Cambridge University Press, Cambridge.

England, A., Eastwood, W.J., Roberts, N., Turner, R., Haldon, J.F., 2008. Historical landscape change in Cappadocia (central Turkey): a palaeoecological investigation of annually-laminated sediments from Nar Lake. The Holocene 18, 1229-1245.

Esper, J., Frank, D.C., Büntgen, U., Verstege, A., Luterbacher, J., Xoplaki, E., 2007. Long-term drought severity variations in Morocco. Geophysical Research Letters 34, L17702.

Euro_Med consortium, 2015. European summer temperatures since Roman times. Environ. Res. Lett., in revision.

Frankopan, P., 2013. Review of Ellenblum, The collapse of the eastern Mediterranean. History Today. Fei, J., Zhou, J., Hou, Y., 2007. Circa A.D. 626 volcanic eruption, climatic cooling, and the collapse of the Eastern Turkic Empire. Climatic Change 81, 469-475. 
Fernández-Donado, L., González-Rouco, J.F., Raible, C.C., Ammann, C.M., Barriopedro, D., GarciaBustamante, E., Jungclaus, J.H., Lorenz, S.J., Luterbacher, J., Phipps, S.J., Servonnat, J., Swingedouw, D., Tett, S.F.B., Wagner, S., Yiou, P., Zorita, E., 2013. Large-scale temperature response to external forcing in simulations and reconstructions of the last millennium. Climate of the Past 9, 393-421. http://dx.doi.org/10.5194/cp-9-393-2013.

Finné, M., Holmgren, K., Sundqvist, H.S., Weiberg, E., Lindblom, M., 2011. Climate in the eastern Mediterranean, and adjacent regions, during the past 6000 years - a review. J. Archaeol. Sci. 38, 3153-3173.

Frankopan, P. 2009. Land and power in the middle and later period. In: Haldon 2009a, 112-142.

Frankopan, P., 2013. Review of Ellenblum, The collapse of the eastern Mediterranean. History Today.

Gao, C., Robock, A., Ammann, C., 2008. Volcanic forcing of climate over the last 1500 years: An improved ice core-based index for climate models. J. Geophys. Res. 113, D23111, http://dx.doi.org/10.1029/2008JD010239.

Ge, Q.-S., Zheng, J.-Y., Hao, Z.-X., Shao, X.-M., Wang, W.-C., Luterbacher, J., 2010. Temperature Variation through 2000 years in China: An Uncertainty Analysis of Reconstruction and Regional Difference. Geophysical Research Letters 37, L03703.

Giorgetta, M.A., Jungclaus, J.H., Reick, C.H., Legutke, S., Bader, J., Böttinger, M., Brovkin, V., Crueger, T., Esch, M., Fieg, K., Glushak, K., Gayler, V., Haak, H., Hollweg, H.-D., Ilyina, T., Kinne, S., Kornblueh, L., Matei, D., Mauritsen, T., Mikolajewicz, U., Mueller, W.A., Notz, D., Pithan, F., Raddatz, T., Rast, S., Redler, R., Roeckner, E., Schmidt, H., Schnur, R., Segschneider, J., Six, K., Stockhause, M., Timmreck, C., Wegner, J., Widmann, H., Wieners, K.-H., Claussen, M., Marotzke, J., Stevens, B., 2013. Climate and carbon cycle changes from 1850 to 2100 in MPI-ESM simulations for the coupled model intercomparison project phase 5. Journal of Advances in Modeling Earth Systems 5, 572-597. http://dx.doi.org/10.1002/jame.20038.

Gogou, A., Triantaphyllou, M., Xoplaki, E., Izdebski, E., Parinos, C., Dimiza, M., Bouloubassi, I., Luterbacher, J., Kouli, K., Martrat, B., Fleitmann, D., Rousakis, G., Kaberi, H., Athanasiou, M., Lykousis, V., submitted. Climate variability and socio-environmental changes in the northern Aegean Sea (Greece) during the last 1500 years. Quaternary Science Reviews.

Göktürk, O.M., 2011. Climate in the Eastern Mediterranean through the Holocene inferred from Turkish stalagmites. PhD-thesis, $130 \mathrm{p}$, University of Bern.

Göktürk, O.M., Fleitmann, D., Badertscher, S., Cheng, H., Edwards, R.L., Leuenberger, M., Fankhauser, A., Tuysuz, O., Kramers, J., 2011. Climate on the southern Black Sea coast during the Holocene: implications from the Sofular Cave record. Quaternary Science Reviews 30, 2433-2445.

Gómez-Navarro, J.J., Montávez, J.P., Wagner, S., Zorita, E., 2013. A regional climate palaeosimulation for Europe in the period 1500-1990 - Part 1: Model validation. Climate of the Past 9, 1667-1682. http://dx.doi.org/10.5194/cp-9-1667-2013.

Goosse, H., Guiot, J., Mann, M.E., Dubinkina, S., Sallaz-Damaz, Y., 2012. The medieval climate anomaly in Europe: Comparison of the summer and annual mean signals in two reconstructions and in simulations with data assimilation. Global and Planetary Change 84-85, 35-47. http://dx.doi.org/10.1016/j.gloplacha.2011.07.002

Goosse, H., Arzel, O., Luterbacher, J., Mann, M.E., Renssen, H., Riedwyl, N., Timmermann, A., Xoplaki, E., Wanner, H., 2006. The origin of the European "Medieval Warm Period", Climate of the Past 2, 99-113. www.climpast.net/2/99/2006/.

Graham, N.E., Ammann, C.M., Fleitmann, D., Cobb, K.M., Luterbacher, J., 2011. Support for global climate reorganization during the "Medieval Climate Anomaly". Climate Dynamics 37, 12171245. http://dx.doi.org/10.1007/s00382-010-0914-z.

Griggs, C., DeGaetano, A., Kuniholm, P., Newton, M., 2007. A regional high-frequency reconstruction of May-June precipitation in the north Aegean from oak tree rings, AD 1089-1989. International Journal of Climatology 27, 1075-1089. 
Guiot, J., 2012. A robust spatial reconstruction of April to September temperature in Europe: Comparisons between the medieval period and the recent warming with a focus on extreme values. Global and Planetary Change 84-85, 14-22.

Guiot, J., Corona, C., ESCARSEL members, 2010. Growing Season Temperatures in Europe and Climate Forcings Over the Past 1400 Years. PLoS ONE 5(4), e9972. http://dx.doi.org/10.1371/journal.pone.0009972.

Hahn, M., 1996. The early Byzantine to modern periods. In: Wells, B., Runnels, C.N. (Eds.), The Berbati-Limnes Archaeological Survey, 1988-1990. Astroms Forlag, Stockholm, pp. 345-451.

Haldon, J., 1997. Byzantium in the Seventh Century: the Transformation of a Culture. Cambridge.

Haldon, J., 1993. The state and the tributary mode of production. Verso, London.

Haldon, J. 2009a, The social history of Byzantium. Oxford

Haldon, J. 2009b. Social élites, wealth and power. In: Haldon, J. (Ed.) The social history of Byzantium.

Oxford, pp. 169-211.

Haldon, J., 2007. "Cappadocia will be given over to ruin and become a desert". Environmental evidence for historically-attested events in the 7th-10th centuries. In: Belke, K. (Ed.), Byzantina Mediterranea: Festschrift Für Johannes Koder Zum 65. Geburtstag. Böhlau, Wien, pp. 215-230.

Harvey, A., 1989. Economic Expansion in the Byzantine Empire, 900-1200. Cambridge University Press, Cambridge.

Haylock, M.R., Hofstra, N., Klein Tank, A.M.G., Klok, E.J., Jones, P.D., New, M., 2008. A European daily high-resolution gridded dataset of surface temperature and precipitation. Journal of Geophysical Research (Atmospheres) 113, D20119. http://dx.doi.org/10.1029/2008JD10201.

Hendy, M.F., 1970. Byzantium, 1081-1204: An Economic Reappraisal. Transactions of the Royal Historical Society 21, 31-52.

Hendy, M.F., 1989. Byzantium, 1081-1204: The Economy Revisited, Twenty Years On. In: Hendy, M.F. (Ed.) The Economy, Fiscal Administration and Coinage of Byzantium, pp. 1-48.

Hennig, R., 1904. Katalog bemerkenswerter Witterungsereignisse von den ältesten Zeiten bis zum Jahre 1800, vol. 2(4). Berlin.

Hughes, M.K., Diaz, H.F., 1994. Was there a 'Medieval Warm Period', and if so, where and when? Climatic Change 26, 109-142.

IPCC, 2013. Annex III: Glossary, Planton, S. (Ed.). In: Stocker, T. et al. (Eds.), Climate Change 2013: The Physical Science Basis. Contribution of Working Group I to the Fifth Assessment Report of the Intergovernmental Panel on Climate Change. Cambridge University Press, Cambridge, United Kingdom and New York, NY, USA.

Izdebski, A., 2013. A rural economy in transition. Asia Minor from Late Antiquity into the Early Middle Ages, Journal of Juristic Papyrology Supplement Series. Taubenschlag Foundation, Warsaw.

Izdebski, A., in press. Byzantine ecologies. In: Decker, M. (Ed.), Cambridge Companion to Byzantine Archaeology. Cambridge University Press, Cambridge.

Izdebski, A., Koloch, G., Słoczyński, T., Tycner-Wolicka, M., 2014. On the Use of Palynological Data in Economic History: New Methods and an Application to Agricultural Output in Central Europe, 0-2000 AD (Working paper No. 54582). Munich Personal RePEc Archive.

Izdebski, A., Koloch, G., Słoczyński, T., 2015. Exploring Byzantine and Ottoman economic history with the use of palynological data: a quantitative approach. Jahrbuch der österreichischen Byzantinistik. in press.

Jeffreys, E., Haldon, J.F., Cormack, R., 2008. The Oxford Handbook of Byzantine Studies. Oxford.

Jones, M.D., Roberts, N., Leng, M.J., Türkeş, M., 2006. A high-resolution late Holocene lake isotope record from Turkey and links to North Atlantic and monsoon climate. Geology 34 (5), 361-364.

Jones, J.M., Widmann, M., 2004. Reconstructing large-scale variability from palaeoclimatic evidence by means of Data Assimilation Through Upscaling and Nudging (DATUN). In: Fischer, H. et al. (eds.), The KIHZ project: towards a synthesis of Holocene proxy data and climate models. Springer, Heidelberg, Berlin, New York. ISSN 1437-028X, p. 171-193. 
Jungclaus, J.H., Lohmann, K., Zanchettin, D., 2014. Enhanced 20th-century heat transfer to the Arctic simulated in the context of climate variations over the last millennium. Climate of the Past 10, 2201-2213. http://dx.doi.org/10.5194/cp-10-2201-2014.

Kaplan, M., 1992. Les hommes et la terre à Byzance du Vle au Xle siècle: propriété et exploitation du sol. Publications de la Sorbonne, Paris.

Kaniewski, D., van Campo, E., Morhange, C., Guiot, J., Zviely, D., et al., 2014. Vulnerability of Mediterranean Ecosystems to Long-Term Changes along the Coast of Israel. PLoS ONE 9(7), e102090. http://dx.doi.org/10.1371/journal.pone.0102090.

Kaniewski, D., van Campo, E., Morhange, C., Guiot, J., Zviely, D., Shaked, I., Otto, T., Artzy, M., 2013. Early urban impact on Mediterranean coastal environments. Sci. Rep. 3, 3540. http://dx.doi.org/10.1038/srep03540.

Kaniewski, D., van Campo, E., Weiss H., 2012. Drought is a recurring challenge in the Middle East. P. Natl. Acad. Sci. USA 109, 3862-3867.

Kendall, M.G., 1975. Rank Correlation Methods. Oxford Univ. Press, New York.

Koder, J., 1984. Der Lebensraum der Byzantiner: historisch-geographischer Abriß ihres mittelalterlichen Staates im östlichen Mittelmeerraum. Nachdruck mit bibliographischen Nachträgen. Byzantinische Geschichtsschreiber; Ergänzungsband 1, Graz.

Kolb, F., 2008. Burg - Polis - Bischofssitz. Geschite der Siedlungskammer von Kyaneai in der Südwesttürkei. Verlag Philip von Zaber, Mainz.

Koukoulis, T., 1997. Medieval Methana. In: Mee, C., Forbes, H.A., Altherton, M.P. (Eds.), A Rough and Rocky Place: The Landscape and Settlement History of the Methana Peninsula, Greece. Liverpool University Press, Liverpool, pp. 92-100.

Kuglitsch, F.G., Toreti, A., Xoplaki, E., Della-Marta, P.M., Zerefos, C.S., Türkes, M., Luterbacher, J., 2010. Heat Wave Changes in the Eastern Mediterranean since 1960. Geophysical Research Letters 37, L04802.

Kuzucuoğlu, C., Dörfler, W., Kunesch, S., Goupille, F., 2011. Mid- to late-Holocene climate change in central Turkey: the Tecer Lake record. The Holocene 21, 173-188.

Laiou, A.E., 1972. Constantinople and the Latins: the foreign policy of Andronicus II, 1282-1328. Harvard University Press.

Laiou, A.E., Morrisson, C., 2007. The Byzantine economy, Cambridge medieval textbooks. Cambridge University Press, Cambridge.

Laiou, A.E., 2002. The economic history of Byzantium from the seventh through the fifteenth century. Washington D.C.

Lamb, H.H., 1965. The early medieval warm epoch and its sequel. Palaeogeography, Palaeoclimatology, Palaeoecology 1, 13-37.

Landrum, L., Otto-Bliesner, B.L., Wahl, E.R., Conley, A., Lawrence, P.J., Rosenbloom, N., Teng, H., 2013. Last Millennium Climate and Its Variability in CCSM4. Journal of Climate 26, 1085-1111. http://dx.doi.org/10.1175/JCLI-D-11-00326.1.

Lavigne, F., Degeai, J.-P., Komorowski, J.-C., Guillet, S., Robert, V., Lahitte, P., Oppenheimer, C., Stoffel, M., Vidal, C.M., Surono, Pratomo, I., Wassmer, P., Hajdas, I., Sri Hadmoko, D., de Beliza, E., 2013. Source of the great A.D. 1257 mystery eruption unveiled, Samalas volcano, Rinjani Volcanic Complex, Indonesia. Proceedings of the National Academy of Sciences of the United States of America 110, 6742-16747.

Ledru, M.-P., Jomelli, V., Samaniego, P., Vuille, M., Hidalgo, S., Herrera, M., Ceron, C., 2013. The Medieval Climate Anomaly and the Little Ice Age in the eastern Ecuadorian Andes. Clim. Past 9, 307-321. http://dx.doi.org/10.5194/cp-9-307-2013

Lefort, J., 1985. Radolibos: population et paysage. Travaux et Mémoires 9, 194-234.

Lefort, J., 1991. Population et peuplement en Macedoine orientale, IXe-XVe siecle. In: Kravari, V., Lefort, J., Morrisson, C. (Eds.) Hommes et richesses dans l'empire byzantin. Publications de la Sorbonne, Paris, pp. 69-71. 
Lefort, J., 2002. The rural economy, seventh-twelfth centuries. In: Laiou, A.E. (Ed.), The Economic History of Byzantium: From the Seventh through the Fifteenth Century, Dumbarton Oaks Studies. Harvard University Press, Dubmbarton Oaks, pp. 232-310.

Li, Y.Y., Zhou, L.P., Cui, H.T., 2008. Pollen indicators of human activity. Chinese Science Bulletin 53, 1281-1293.

Lohmann, H., 1995. Survey in der Chora von Milet: Vorbericht über die Kampagnen der Jahre 1990, 1992 und 1993. Archäologischer Anzeiger, 293-328.

Luterbacher. J., García-Herrera, R., Allan, A.R., Alvarez-Castro, M.C., Benito, G., Booth, J., Büntgen, U., Colombaroli, D., Davis, B., Esper, J., Felis, T., Fleitmann, D., Frank, D., Gallego, D., GarciaBustamante, E., González-Rouco, J.F., Goosse, H., Kiefer,T., Macklin, M.G., Montagna, P., Newman, L., Power, M.J., Rath, V., Ribera, P., Roberts, N., Silenzi, S., Tinner, W., Valero-Garces, B., van der Schrier, G., Vannière, B., Wanner, H., Werner, J.P., Willett, G., Xoplaki, E., Zerefos, C.S., Zorita, E., 2012. A review of 2000 years of paleoclimatic evidence in the Mediterranean. In: Lionello, P. (Ed.), The Climate of the Mediterranean Region. From the past to the future. Elsevier, Amsterdam, The Netherlands, pp. 89-185. http://dx.doi.org/10.1016/B978-0-12416042-2.00002-1.

Magdalino, P., 2008. The Empire of the Komnenoi (1118-1204). In: Shepard, J. (Ed.), The Cambridge History of the Byzantine Empire C. 500--1492. Cambridge University Press, Cambridge, pp. 627663.

Mann, H.B., 1945. Non-parametric tests against trend, Econometrica 13, 163-171.

Mann, M.E., Zhang, Z.H., Rutherford, S., Bradley, R.S., Hughes, M.K., Shindell, D., Ammann, C.M., Faluvegi, G., Ni, F.B., 2009. Global signatures and dynamical origins of the Little Ice Age and Medieval Climate Anomaly. Science 326, 1256-1260.

Marin, J., 2008. Byzantium and the Dark Ages. A civilization on trial. In: Imago temporis. Medium aevum, 2, Lleida, Spain, pp. 59-82.

Marotzke, J., Forster, P.M., 2015. Forcing, feedback and internal variability in global temperature trends. Nature 517, 565-570. http://dx.doi.org/ 10.1038/nature14117.

Masson-Delmotte, V., Schulz, M., Abe-Ouchi, A., Beer, J., Ganopolski, A., González Rouco, J.F., Jansen, E., Lambeck, K., Luterbacher, J., Naish, T., Osborn, T., Otto-Bliesner, B., Quinn, T., Ramesh, R., Rojas, M., Shao, X., Timmermann, A., 2013. Information from Paleoclimate Archives. In: Stocker, T.F. et al. (Eds.), Climate Change 2013: The Physical Science Basis. Contribution of Working Group I to the Fifth Assessment Report of the Intergovernmental Panel on Climate Change. Cambridge University Press, Cambridge, United Kingdom and New York, NY, USA.

Matsikaris, A., Widmann, M., Jungclaus, J., 2015. On-line and off-line data assimilation in palaeoclimatology: a case study. Clim. Past 11, 81-93. http://dx.doi.org/10.5194/cp-11-81-2015.

Matthews, R., Metcalfe, M., Cottica, D., 2009. Landscapes with Figures: Paphlagonia through the Hellenistic, Roman and Byzantine Periods, 330 BC-AD 1453. In: Glatz, C., Matthews, R. (Eds.), At Empire's Edge: Project Paphlagonia: Regional Survey in North-Central Turkey. British Institute of Archaeology at Ankara, London, pp. 173-236.

Maunder, E.W., 1922. The prolonged sunspot minimum 1675-1715. British Astronomical Association Journal 32, 140-145.

Meehl, G.A., Washington, W.M., Arblaster, J.M., Hu, A., Teng, H., Tebaldi, C., Sanderson, B.N., Lamarque, J.-F., Conley, A., Strand, W.G, White, J.B. III, 2012. Climate System Response to External Forcings and Climate Change Projections in CCSM4. Journal of Climate 25, 3661-3683. http://dx.doi.org/10.1175/JCLI-D-11-00240.1

Metcalf, D.M., 1960. The Currency of Byzantine Coins in Smyrna and Slavonia. Hamburger Beiträge zur Numismatik 14, 429-444.

Morrisson, C., 1976. La dévaluation de la monnaie byzantine au Xle siècle: essai d'interprétation. Travaux et Mémoires du Centre de Recherche d'Histoire et Civilisation de Byzance 6, 3-48.

Morrisson, C., 1991. Monnaie et finances dans I'Empire byzantine Xe-XIVe siècle. In: Kravari, V., Lefort, J., Morrisson, C. (Eds.) Hommes et richesses dans l'empire byzantin, Réalités Byzantines. Lethielleux, Paris, pp. 291-315. 
Morrisson, C., 2001. Survivance de l'économie monétaire à Byzance (VIle-IXe siècle). In: KountouraGalakè, E. (Ed.), Hoi Skoteinoi Aiones Tou Vyzantiou (7os - 9os Ai.) (The dark centuries of Byzantium, 7th-9th c.). Ethniko Hidryma Ereunon, Institouto Vyzantinon, Athens, pp. 377-397.

Morrisson, C., 2002. Byzantine Money: Its Production and Circulation. In: Laiou, A.E. (Ed.), The Economic History of Byzantium: From the Seventh through the Fifteenth Century. Harvard University Press, Dubmbarton Oaks, pp. 909-966.

Mothes, P.A., Hall, M.L., 2008. The Plinian fallout associated with Quilotoa's 800yr BP eruption, Ecuadorian Andes. J. Volanol. Geotherm. Res. 176, 56-69.

Müller-Wiener, W., 1961. Mittelalterliche Befestigungen im südlichen Jonien. Istanbuler Mitteilungen $11,5-122$.

Oikonomidès, N., 1991. Terres du fisc et revenue de la terre aux Xe-Xle siècle. In: Hommes et richesses dans l'empire byzantin, Réalités Byzantines. Lethielleux, Paris, pp. 321-337.

Oikonomidès, N., 1996. Fiscalité et exemption fiscale à Byzance (IXe-Xle s.). Fondation nationale de la recherche scientifique, Athènes.

PAGES 2k Consortium: Ahmed, M., Anchukaitis, K.J., Asrat, A., Borgaonkar, H.P., Braida, M., Buckley, B.M., Büntgen, U., Chase, B.M., Christie, D.A., Cook, E.R., Curran, M.A.J., Diaz, H.F., Esper, J., Fan, Z-X., Gaire, N.P., Ge, Q., Gergis, J., González-Rouco, J.F., Goosse, H., Grab, S.W., Graham, N., Graham, R., Grosjean, M., Hanhijärvi, S.T., Kaufman, D.S., Kiefer, T., Kimura, K., Korhola, A.A., Krusic, P.J., Lara, A., Lézine, A-M., Ljungqvist, F.C., Lorrey, A.M., Luterbacher, J., MassonDelmotte, V., McCarroll, D., McConnell, J.R., McKay, N.P., Morales, M.S., Moy, A.D., Mulvaney, R., Mundo, I.A., Nakatsuka, T., Nash, D.J., Neukom, R., Nicholson, S.E., Oerter, H., Palmer, J.G., Phipps, S.J., Prieto, M.R., Rivera, A., Sano, M., Severi, M., Shanahan, T.M., Shao, X., Shi, F., Sigl, M., Smerdon, J.E., Solomina, O.N., Steig, E. J., Stenni, B., Thamban, M., Trouet, V., Turney, C.S.M., Umer, M., van Ommen, T., Verschuren, D., Viau, A.E., Villalba, R., Vinther, B.M., von Gunten, L., Wagner, S., Wahl, E.R., Wanner, H., Werner, J.P., White, J.W.C., Yasue, K., Zorita, E., 2013. Continental-scale temperature variability during the last two millennia. Nature Geoscience 6, 339-346.

Pfister, C., Kington, J., Kleinlogel, G., Schüle, H., Siffert, E., 1994. High Resolution Spatio-Temporal Reconstructions of Past Climate from Direct Meteorological Observations and Proxy-Data. In: Fischer, G. (Ed.), Climatic Trends and Anomalies in Europe 1675-1715. Stuttgart, pp. 329-375.

Pongratz, J., Reick, C.H., Raddatz, T., Claussen, M., 2008. A reconstruction of global agricultural areas and land cover for the last millennium. Global Biogeochem. Cycles 22, GB3018. http://dx.doi.org/10.1029/2007GB003153.

Psellus, M., 1829. Peri Georgikon. In: Boissonade, J.-P., Anecdota Graeca 1. Paris, pp. 242-247. Ritter, M., 2013. Die vlacho-bulgarische Rebellion und die Versuche ihrer Niederschlagung durch Kaiser Isaakios II. (1185-1195). Byzantinoslavica 71, 162-210.

Roberts, N., Moreno, A., Valero-Garcés, B.L., Corella, J.P., Jones, M., Allcock, S., Woodbridge, J., Morellón, M., Luterbacher, J., Xoplaki, E., Turkes, M., 2012. Palaeolimnological evidence for an east-west climate see-saw in the Mediterranean since AD 900. Global and Planetary Change 84, 23-34.

Schmidt, G.A., Jungclaus, J.H., Ammann, C.M., Bard, E., Braconnot, P., Crowley, T.J., Delaygue, G., Joos, F., Krivova, N.A., Muscheler, R., Otto-Bliesner, B.L., Pongratz, J., Shindell, D.T., Solanki, S.K., Steinhilber, F., Vieira, L.E.A., 2012. Climate forcing reconstructions for use in PMIP simulations of the Last Millennium (v1.1). Geosci. Model Dev. 5, 1850191. http://dx.doi.org/10.5194/gmd-5185-2012.

Sen, P.K., 1968. Estimates of the regression coefficient based on Kendall's tau. Journal of the American Statistical Association 63, 1379-1389.

Sen Gupta, A., Jourdain, N.C., Brown, J.N. and Monselesan, D., 2013. Climate Drift in the CMIP5 Models. Journal of Climate 26, 8597-8615. http://dx.doi.org/10.1175/JCLI-D-12-00521.1.

Schneider, D.P., Ammann, C.M., Otto-Bliesner, B.L., Kaufman, D.S., 2009. Climate response to large, high-latitude and low-latitude volcanic eruptions in the Community Climate System Model. Journal of Geophysical Research 114, D15101. http://dx.doi.org/10.1029/2008JD011222. 
Shindell, D.T., Schmidt, G.A., Miller, R.L., Mann, M.E., 2003. Volcanic and solar forcing of climate change during the preindustrial era. Journal of Climate 16, 4094-4107.

Sigl, M., Winstrup, M., McConnell, J.R., Welten, K.C., Plunkett, G., Ludlow, F., Büntgen, U., Caffee, M., Chellman, N., Dahl-Jensen, D., Fischer, H., Kipfstuhl, S., Kostick, C., Maselli, O.J., Mekhaldi, F., Mulvaney, R., Muscheler, R., Pasteris, D.R., Pilcher, J.R., Salzer, M., Schüpbach, S., Steffensen, J.P., Vinther, B.M., Woodruff, T.E., 2015. Timing and climate forcing of volcanic eruptions for the past 2,500 years. Nature 523, 543-549. http://dx.doi.org/10.1038/nature14565

Stathakopoulos, D., 2004. Famine and Pestilence in the Late Roman and Early Byzantine Empire: A Systematic Survey of Subsistence Crises and Epidemics. Birmingham Byzantine and Ottoman Monographs 9, Aldershot-Burlington.

Steiger, N.J., Hakim, G.J., Steig, E.J., Battisti, D.S., Roe, G.H., 2014. Assimilation of time-averaged pseudoproxies for climate reconstruction. Journal of Climate 27, 426-441. http://dx.doi.org/10.1175/JCLI-D-12-00693.1

Stine, S., 1994. Extreme and persistent drought in California and Patagonia during medieval time. Nature 269, 546-549.

Stoffel, M., Khodri, M., Corona, C., Guillet, S., Poulain, V., Bekki, S., Guiot, J., Luckman, B.H., Oppenheimer, C., Lebas, N., Beniston, M., Masson-Delmotte, V., 2015. Estimates of volcanicinduced cooling in the Northern Hemisphere over the past 1,500 years. Nature Geoscience. http://dx.doi.org/10.1038/NGEO2526.

Tartaron, T.F., Gregory, T.E., Pullen, D.J., Noller, J.S., Rothaus, R.M., Rife, J.L., Tzortzopoulou-Gregory, L., Schon, R., Caraher, W.R., Pettegrew, D.K., Nakassis, D., 2006. The Eastern Korinthia Archaeological Survey: Integrated Methods for a Dynamic Landscape. Hesperia: The Journal of the American School of Classical Studies at Athens 75, 453-523.

Taylor, K.E., Stouffer, R.J., Meehl, G.A., 2012. An overview of CMIP5 and the experiment design. Bulletin of the American Meteorological Society 93, 485-498. http://dx.doi.org/10.1175/BAMSD-11-00094.1.

Teall, J.L., 1971. The Byzantine Agricultural Tradition. Dumbarton Oaks Papers 25, 33-59.

Telelis, I.G., 2000. Medieval Warm Period and the beginning of the Little Ice Age in Eastern Mediterranean. An approach of physical and anthropogenic evidence. In Belke, K. et al. (eds.), Byzanz als Raum. Zu Methoden und Inhalten der historischen Geographie des Östlichen Mittelmeerraumes. Veröffentlichung der Kommission für die Tabula Imperii Byzantini. Denkschrift 7, Wien, pp. 223-243.

Telelis, I.G., 2004. Meteorological Phenomena and Climate in Byzantium, 2 vols. Academy of Athens, Ponimata No. 5, p. 924 (in Greek with English summary), Athens.

Telelis, I.G., 2005. Historical-climatological Information from the Time of the Byzantine Empire (4th15th Centuries AD). History of Meteorology 2, 41-50.

Telelis, I.G., 2008. Climatic fluctuations in the Eastern Mediterranean and the Middle East AD 3001500 from Byzantine documentary and proxy physical paleoclimatic evidence - a comparison. Jahrbuch der Oesterreichischen Byzantinistik 58, 167-207.

Telelis, I.G., Chrysos, E., 1992. The Byzantine Sources as Documentary Evidence for the Reconstruction of Historical Climate. In: Frenzel, B. (Ed.), European climate reconstructed from documentary data: Methods and results, European Palaeoclimate and Man No 2, Stuttgart-JenaNew York, pp. 17-31.

Thonemann, P., 2011. The Maeander Valley: a historical geography from antiquity to Byzantium. Cambridge University Press, Cambridge.

Timmreck, C., Lorenz, S.J., Crowley, T.J., Kinne, S., Raddatz, T.J., Thomas, M.A., Jungclaus, J.H., 2009. Limited temperature response to the very large AD 1258 volcanic eruption. Geophys. Res. Lett. 36, L21708.

Toohey, M., Kruger, K., Niemeier, U., Timmreck, C., 2011. The influence of eruption season on the global aerosol evolution and radiative impact of tropical volcanic eruptions. Atmos. Chem. Phys. 11, 12,351-12,367. http://dx.doi.org/10.5194/acp-11-12351-2011. 
Toreti, A., 2010. Extreme Events in the Mediterranean: Analysis and Dynamics. Ph.D. Thesis. University of Bern, Switzerland.

Toreti, A., Xoplaki, E., Maraun, D., Kuglitsch, F.G., Wanner, H., Luterbacher, J., 2010. Characterisation of extreme winter precipitation in Mediterranean coastal sites and associated anomalous atmospheric circulation patterns. Nat. Hazards Earth Syst. Sci. 10, 1037-1050.

Tous, J., Ferguson, L., 1996. Mediterranean fruits. In: Janick, J. (Ed.), Progress in New Crops. ASHS Press, Arlington, pp. 416-430.

Treadgold, W.T., 1982. The Byzantine State Finances in the Eighth and Ninth Centuries, East European monographs. East European Monographs, Boulder.

Türkeş, M., 1996. Spatial and temporal analysis of annual rainfall variations in Turkey. International Journal of Climatology 16, 10571076.

Ulbrich, U., Lionello, P., Belušić, D., Jacobeit, J., Knippertz, P., Kutiel, H., Kuglitsch, F.G., Leckebusch, G.C., Luterbacher, J., Maugeri, M., Nissen, K.M., Pavan, V., Pinto, J.G., Saaroni, H., Seubert, S., Toreti, A., Xoplaki, E., Ziv, B., 2012. Synoptic climatology of the Mediterranean and trends. In: Lionello, P. (Ed.), The Climate of the Mediterranean Region. From the past to the future. Elsevier, Amsterdam, The Netherlands. http://dx.doi.org/10.1016/B978-0-12-416042-2.00005-7.

Vanhaverbeke, H., Waelkens, M., 2003. The Chora of Sagalassos: the evolution of the settlement pattern from prehistoric until recent times, Studies in eastern Mediterranean archaeology. Brepols, Turnhout.

Vieira, L.E.A., Solanki, S.K., Krivova, N.A., Usoskin, I., 2011. Evolution of the solar irradiance during the Holocene. Astron. Astrophys. 531, A6. http://dx.doi.org/10.1051/0004-6361/201015843.

Vionis, A.K., 2008. Current Archaeological Research on Settlement and Provincial Life in the Byzantine and Ottoman Aegean: A Case-Study from Boeotia, Greece. Medieval Settlement Research 23, 28-41.

Vroom, J., 2005. Byzantine to Modern Pottery in the Aegean: 7th to 20th Century: An Introduction and Field Guide. Utrecht: Parnassus Press.

Wagner, S., Widmann, M., Jones, J., Haberzettl, T., Lücke, A., Mayr, C., Ohlendorf, C., Schäbitz, F., Zolitschka, B., 2007. Transient simulations, empirical reconstructions and forcing mechanisms for the Mid-Holocene hydrological climate in Southern Patagonia. Climate Dynamics 29, 333 355. http://dx.doi.org/10.1007/s00382-007-0229-x.

Weikinn, C., 1958. Quellentexte zur Witterungsgeschichte Europas von der Zeitwende bis zum Jahre 1850. I. Hydrographie. I. Teil: Zeitwende -1500. Berlin, Akademie-Verl., p. 531.

Widmann, M., Goosse, H., van der Schrier, G., Schnur, R., Barkmeijer, J., 2010. Using data assimilation to study extratropical Northern Hemisphere climate over the last millennium. Climate of the Past 6, 627-644.

Xoplaki, E., González-Rouco, F., Luterbacher, J., Wanner, H., 2004. Wet season Mediterranean precipitation variability: influence of large-scale dynamics and trends. Clim. Dyn. 23, 63-78.

Xoplaki, E., J. F. González-Rouco, J. Luterbacher, and H. Wanner, 2003: Mediterranean summer air temperature variability and its connection to the large scale atmospheric circulation and SSTs. Climate Dynamics 20, 723-739

Xoplaki, E., Maheras, P., Luterbacher, J., 2001. Variability of climate in meridional Balkans during the periods 1675-1715 and 1780-1830 and its impact on human life. Climatic Change 48, 581-615. 